\title{
Novel Tacrine-Grafted Ugi Adducts as multipotent Anti-Alzheimer Drugs: A Synthetic Renewal in Tacrine-Ferulic Acid Hybrids
}

\author{
Mohamed Benchekroun, ${ }^{[\mathrm{a}]}$ Manuela Bartolini, ${ }^{[\mathrm{b}]}$ Javier Egea, ${ }^{[\mathrm{c}]}$ Alejandro Romero, ${ }^{[\mathrm{d}]}$ Elena Soriano, ${ }^{[\mathrm{e}]}$ \\ Marc Pudlo, ${ }^{[\mathrm{a}]}$ Vincent Luzet, ${ }^{[\mathrm{a}]}$ Vincenza Andrisano, ${ }^{[\mathrm{fl}}$ María-Luisa Jimeno, ${ }^{[\mathrm{g}]}$ Manuela G. López, ${ }^{[\mathrm{c}]}$ Sarah \\ Wehle, ${ }^{[\mathrm{h}]}$ Tijani Gharbi, ${ }^{[\mathrm{a}]}$ Bernard Refouvelet, ${ }^{[\mathrm{a}]}$ Lucía de Andrés, ${ }^{[\mathrm{i}]}$ Clara Herrera-Arozamena, ${ }^{[\mathrm{i}]}$ Barbara \\ Monti, ${ }^{[b]}$ Maria Laura Bolognesi, ${ }^{[b]}$ María Isabel Rodríguez-Franco, ${ }^{[i]}$ Michael Decker, ${ }^{[\mathrm{b}]}$ José Marco- \\ Contelles, ${ }^{*[]]}$ and Lhassane Ismaili*[a]
}

\begin{abstract}
We describe here the design, multicomponent synthesis, biological studies, molecular modeling, ADMET, and in vitro PAMPA-BBB analysis of new tacrine-ferulic acid hybrids (TFAHs). We have identified TFAH 10n as interesting multipotent compound showing moderate, and totally selective, hBuChE inhibition ( $\left.\mathrm{IC}_{50}=68.2 \mathrm{~nm}\right)$, strong antioxidant activity (4.29 $\mu \mathrm{mol}$ of trolox equivalents, ORAC), and anti-aggregating properties $(65.6 \%$ at $1: 1$ ratio), being able to penetrate CNS (PAMPA-BBB assay). Noteworthy, even when tested at a very high concentration TFAH 10n surpasses by far the other TFAHs in the hepatotoxicity profile $(59.4 \%$ cell viability at $1000 \mu \mathrm{m})$, affording good neuroprotection capacity against toxic insults such as $\mathrm{A} \beta_{1-40}, \mathrm{~A} \beta_{1-42}, \mathrm{H}_{2} \mathrm{O}_{2}$, and oligomycin $\mathrm{A}$ /rotenone on $\mathrm{SH}$ SY5Y cells, at $1 \mu \mathrm{m}$. The results reported here support and strengthen the interest on the development of new multipotent TFAHs derivatives as potential drugs for AD patients cure.
\end{abstract}

\section{Introduction}

Alzheimer's disease (AD) is a neurodegenerative disorder characterized by progressive cognitive impairment and memory loss, associated with the deficit in the cholinergic neurotransmission. ${ }^{[1]}$ Histological changes underlying this disorder are amyloid plaques of $\beta$-amyloid $(\mathrm{A} \beta)$ peptide, neurofibrillary tangles (NFT), a dramatic loss of synapses and neurons, and a decreased level of choline acetyltransferase that correlates with a decline in the mental status scores. ${ }^{[2]}$

Due to the multi-pathogenesis of $A D$, one of the current drug discovery approaches for $A D$ treatment focuses on compounds with a multitarget biological profile, the so called Multi-Target Directed Ligands (MTDLs). ${ }^{[3]}$ The so far developed MTDLs include derivatives which can simultaneously restore the brain acetylcholine (ACh) levels, reduce the oxidative stress, inhibit $\mathrm{A} \beta$ aggregation, and protect neuronal cells against toxic insults. $^{[4-6]}$ Two cholinesterase enzymes, acetylcholinesterase (AChE) and butyrylcholinesterase (BuChE), are responsible for the hydrolysis of the neurotransmitter ACh in the brain. Recent evidence has highlighted non classic role for cholinergic enzymes which may be important in the light of developing more effective drugs for AD. Indeed, it was shown that several AChE inhibitors (AChEls) not only facilitate cholinergic transmission, but also interfere with the synthesis, deposition and aggregation of toxic $\mathrm{A} \beta{ }^{[7,8]}$ On the other hand, other studies suggested that BuChE may also influence the aggregation of $\mathrm{A} \beta$ into neuritic plaques and formation of the NFT deposit. ${ }^{[9,10]}$ Oxidative stress is also thought to play a key role in the pathogenesis of $A D$. Indeed many studies showed that senile plaques release reactive oxygen species (ROS), ${ }^{[11]}$ whose accumulation damages major [a] M. Benchekroun, Dr. M. Pudlo, V. Luzet, Prof. T. Gharbi, Prof. B. Refouvelet, Dr. L. Ismaili NanoMedicine, Imagery and Therapeutics Lab EA 4662 Laboratoire de Chimie Organique et Thérapeutique CHRU Jean Minjoz, Université de Franche-Comté 19, rue Ambroise Paré, 25030-Besançon, France. E-mail: Ihassane.ismaili@univ-fcomte.fr

[b] Dr. M. Bartolini, Prof. B. Monti, Prof. M. L. Bolognesi Department of Pharmacy and Biotechnology Alma Mater Studiorum-University of Bologna Via Belmeloro 6, 40126-Bologna, Italy.

[c] Dr. J. Egea, Dr. M. G. López Instituto Teófilo Hernando and Departamento de Farmacología y Terapéutica Facultad de Medicina, Universidad Autónoma de Madrid C/ Arzobispo Morcillo 4, 28029-Madrid, Spain.

[d] Dr. A. Romero

Departamento de Toxicología y Farmacología Facultad de Veterinaria

Universidad Complutense de Madrid 28040-Madrid, Spain

[e] Dr. E. Soriano

SEPCO (IQOG, CSIC)

C/ Juan de la Cierva 3, 28006-Madrid, Spain.

[f] Prof. V. Andrisano

Department for Life Quality Studies

University of Bologna

Corso di Augusto, 237, 47921-Rimini, Italy.

[g] Dr. M.-L. Jimeno

CENQUIOR (CSIC)

C/ Juan de la Cierva 3, 28006-Madrid, Spain.

[h] S. Wehle, Prof. Dr. M. Decker

Pharmazeutische und Medizinische Chemie,

Institut für Pharmazie und Lebensmittelchemie Julius-Maximilians-Universität Würzburg Würzburg Am Hubland, 97074-Würzburg, Germany.

[i] L. de Andrés, C. Herrera-Arozamena, Prof. M. I. Rodríguez-Franco Instituto de Quimica Médica (IQM-CSIC)

C/ Juan de la Cierva 3, 28006-Madrid, Spain.

[j] Prof. J. Marco-Contelles

Laboratorio de Química Médica (IQOG, CSIC)

C/ Juan de la Cierva 3, 28006-Madrid, Spain.

E-mail: iqog21@iqog.csic.es

Supporting information for this article is given via a link at the end of the document.

cell components, such as the nucleus, mitochondrial DNA, membranes, and cytoplasmic proteins. ${ }^{[12]}$

Notwithstanding the impressive progress in the understanding of the molecular mechanisms at the basis of $A D$, nowadays an effective drug is still not available and AChEls, such as rivastigmine, galantamine and donepezil, remain the principal class of available drugs for the treatment of this disease. ${ }^{[13]}$ Tacrine 1 (Figure 1) a potent, submicromolar human $\mathrm{AChEl}$, the first approved drug ${ }^{[14]}$ by FDA for the treatment of $A D$ in 1993, was withdrawn shortly after its approval, ${ }^{[15]}$ because of its liver 
toxicity. In spite of this, studies on tacrine analogues have been continued $^{[16]}$ in the search of more potent and safer tacrine derivatives. In this light, it is worth to mention that the 7-methoxy derivative of tacrine (7-MEOTA, 9-amino-7-methoxy-1,2,3,4tetrahydroacridine $)^{[17]}(2$, Figure 1$)$, showed reduced hepatotoxicity when compared to tacrine. ${ }^{[18-20]}$

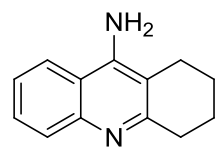

Tacrine (1)<smiles>COc1ccc2nc3c(c(N)c2c1)CCCC3</smiles>

7-MEOTA (2)<smiles>COc1cc(/C=C/C(=O)NCCCNc2c3c(nc4ccccc24)CCCC3)ccc1OCCC[N+](=O)[O-]</smiles>

3<smiles>O=C(/C=C/c1ccc(O)c(O)c1)NCCCNc1c2c(nc3ccccc13)CCCC2</smiles>

4

Figure 1. Structures of tacrine (1), 7-MEOTA (2) and tacrine-ferulic acid hybrids 3 and 4.

On the other hand, based on the MTDLs approach, recent reports have described tacrine hybrids, prepared by connecting tacrine, or its derivatives to other pharmacologically relevant scaffolds with the aim to overcome tacrine's hepatotoxicity ${ }^{[21]}$ among them which the tacrine hybrids, such as the antioxidant tacrine-ferulic acid-nitric oxide (NO) donor (hybrid 3, Figure 1), ${ }^{[22]}$ or the tacrine-caffeic acid (hybrid 4, Figure 1). ${ }^{[23]}$ One of us has recently shown that tacrine-ferulic acid hybrid (TFAH 5a, Figure 2) is a moderate antioxidant and potent reversible, noncompetitive AChEl. Hybrid $\mathbf{5 a}$ is able to bind the peripheral binding site (PAS) of the AChE, showing almost equipotent capacity to inhibit EeAChE and eqBuChE. ${ }^{[24]}$ In addition the TFAH 5b (Figure 2) described by $\mathrm{Pi}$ et al. ${ }^{[25]}$ showed significant in vitro inhibition of $A C h E$-induced and self-induced $A \beta_{1-40}$ aggregation and blocked the cell death induced by $A \beta_{1-40}$ in PC12 cells.
From a synthetic point of view, multicomponent reactions have emerged as the method of choice for introducing molecular diversity. ${ }^{[26]}$ Therefore, they seem well-suited for the search of new molecules having different moieties of interest and able to interact with various physiopathological events in connexion with $A D .^{[4,27-29]}$ Particularly interesting among these types of reactions is the Ugi four-component reaction. This transformation allows creating up to five points of structural diversity in one-pot which can be very useful for the expeditious synthesis of bioactive molecules for multifactorial diseases such as AD. ${ }^{[30]}$

In this context and following a docking-driven combinatorial strategy, Dickerson et al. have prepared a library of Ugi adducts based on a planar and rigid naphthalene moiety, the so-called "credit-card" compounds. ${ }^{[31]}$ As an example, the adduct 5c depicted in Figure 2, is only able to fix to the hydrophobic PAS of AChE, with its naphthalene moiety, which disrupts the existing hydrophobic interactions between $\mathrm{AChE}$ and $\mathrm{A} \beta$, therefore inhibiting $\mathrm{AChE}$-induced $\mathrm{A} \beta$ aggregation. Furthermore, authors have also reported that the observed inhibitory activity is not simply elicited by the naphthalene fragment but very likely also due to the presence of the substituted $\alpha$-acylaminocarboxamide backbone.

Considering these precedents and in order to take advantage of the chemical diversity rapidly achievable by the Ugi reaction as a part of the discovery of new MTDLs for AD therapy, we report here the design, synthesis and biological evaluation of a new family of TFAHs, namely $(E)$-3-(4-hydroxy-3methoxyphenyl)- $N$-alkyl- $N$-[2-oxo-2(amino)ethyl]acrylamides (I, Figure 2). These molecules possess a substituted glycine substructure being part of the main $\alpha$-acylaminocarboxamide backbone. Consequently, the new adducts contains a tacrine or a 7-MEOTA motifs, and a feruloyl group, both tethered to the glycine fragment. The carbonyl group of the glycine part has been functionalized as an amide either by benzylamine, 2'chloro-6'-methylaniline or 2'-naphthylamine which should confer potential and additional anti-cholesterasic, and antioxidant properties to the target molecules. In addition, we have hypothesized that the substituted glycine substructure in our adducts would afford additional aromatic groups able to bind at the AChE's hydrophobic PAS, with potential consequences on the aggregation of $\mathrm{A} \beta$. $^{[32]}$

Therefore, we have synthesized fourteen new TFAHs, identified as hybrids 10a-n (Figure 3), and evaluated their hepatotoxicity on HepG2 cells, the neuroprotective capacity of some selected hybrids against several toxic insults such as $A \beta_{1}$. ${ }_{40}, \mathrm{~A} \beta_{1-42}, \mathrm{H}_{2} \mathrm{O}_{2}$, and oligomycin $\mathrm{A} /$ rotenone, as well as their ChEs inhibition, $\mathrm{A} \beta_{1-42}$ self-aggregation inhibition, antioxidant activity (ORAC-FL scavenging test).

From these studies, we have identified TFAH 10n [(E)-3 (4-hydroxy-3-methoxyphenyl)- $N$-(8-((7-methoxy-1,2,3,4tetrahydroacridin-9-yl)amino)octyl)- $N$-(2-(naphthalen-2-ylamino)2-oxoethyl)acrylamide], as new and very promising multipotent hit molecule for further drug discovery steps for AD. 
MDTLs strategy

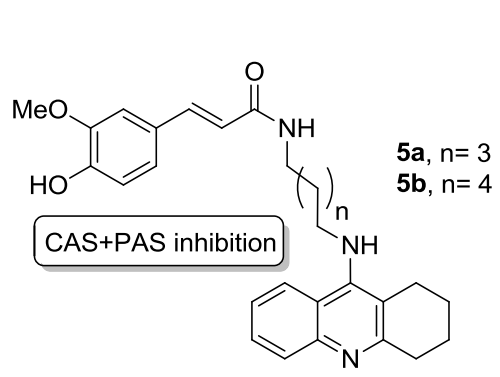

Tacrine-ferulic acid hybrids

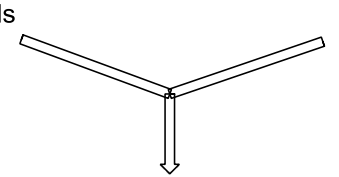

Multicomponent strategy

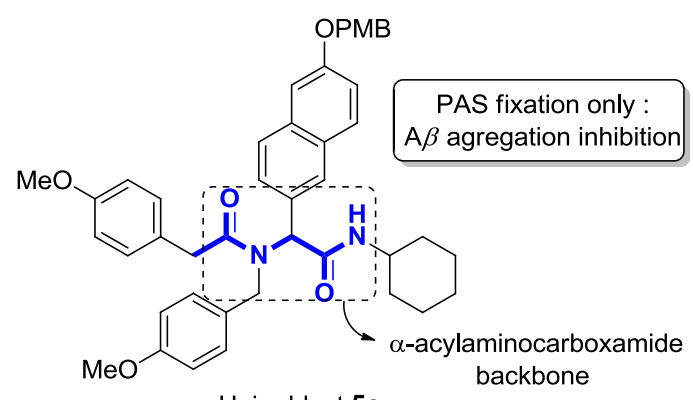

Ugi adduct 5c

multiplicity-edited $\mathrm{gHSQC}$ and gHMBC) (see Supporting Information).

Hybrids 10a-k bear a tacrine moiety while TFAHs $\mathbf{1 0 I - n}$ are 7-MEOTA derivatives. As shown in scheme 1 , in the tacrine hybrids $10 \mathbf{a}-\mathbf{k}, R^{2}$ may be either benzyl, 2'-chloro-6'methylphenyl, or 2'-naphthyl group, depending of the commercial isocyanide used for their synthesis, and the length of the linker varies between 5 and 9 methylene units. On the other hand, for hybrids 10I-n, the linker was kept at $n=8$, while, similarly to hybrids $10 \mathrm{a}-\mathbf{k}$, $\mathrm{R}^{2}$ may be a benzyl, 2'-chloro6'-methylphenyl, or 2'-naphthyl residue.

\section{Biological evaluation}

The in vitro biological evaluation of the new TFAHs 10a-n started with the investigation of the toxicity profile on HepG2 cells,

Figure 2. Structures of compounds 5a-c, and the general structure for the new (E)-3-hydroxy-3-methoxyphenyl- $N$-alkyl- $N$-[(2-oxo-2-amino)ethyl]acrylamides described in this work.

\section{Results and Discussion}

\section{Chemistry}

The synthesis of the target TFAHs 10a-n has been carried out using the short synthetic procedure depicted in scheme 1, with good overall yields.

9-chlorotacrines $\mathbf{8} \mathbf{a}-\mathbf{b}$ were synthesized following known procedures. ${ }^{[33-35]}$ The latter chloro compounds were then reacted with the suitable alkylenediamines in refluxing 1-pentanol to obtain the diamines 9a-f. Diamines were then reacted, by the one-pot U-4CR, with formaldehyde, ferulic acid and selected, commercial isocyanides, in $\mathrm{MeOH} / \mathrm{CH}_{2} \mathrm{Cl}_{2}(3: 1, \mathrm{v} / \mathrm{v})$ at room temperature for $24 \mathrm{~h}$, to obtain the expected TFAHs 10a-n in $16 \%-48 \%$ yield range (Scheme 1). ${ }^{[36]}$

All new TFAHs showed analytical and spectroscopic data in good agreement with their structure. The structural characterization of the synthesized (E)-3-(4-hydroxy-3methoxyphenyl)- $N$-alkyl- $N$-[2-oxo-2-(amino)ethyl]acrylamides 10a-n was carried out by NMR. At $298 \mathrm{~K}$, these compounds showed broadened NMR spectra or even multiple NMR signals indicative of their conformational mobility, which is related to the existence of two or more conformers in solution, as confirmed by an in-depth NMR analysis on selected compounds (variable temperature ${ }^{1} \mathrm{H},{ }^{13} \mathrm{C}$, gCOSY, TOCSY, NOESY, ROESY, and continued with the determination of the ability of the new TFAHs to possess a suitable activity profile on the selected targets, including neuroprotection, inhibition of ChEs activity, antioxidant capacity and inhibition of the $A \beta_{1-42}$ self-aggregation.

\section{Evaluation of hepatoxicity on HepG2 cells}

For the tacrine hybrids 10a-n, the first and the most critical aspect was the evaluation of the hepatotoxicity ${ }^{[37]}$ (see Experimental Part), in a wide concentration range (1-1000 $\mu \mathrm{m})$. The assay was carried out on HepG2 cells using the MTT assay for the cell viability test. ${ }^{[38]}$ As expected, tacrine showed a dosedependent cell toxicity (Table 1), the inflexion point starting at $100 \mu \mathrm{m}$. In general, the hepatotoxic effect of TFAHs 10a-n after $24 \mathrm{~h}$ incubation was lower than that exerted by tacrine. Concerning the structure-activity relationships (SAR), and based on the observed values at $1000 \mu \mathrm{m}$ (the highest concentration investigated), several conclusions can be drawn. Not surprisingly, and in agreement with the rationale of their design, the hybrids carrying the 7-MEOTA fragment (10I-n) were less toxic than the tacrine hybrids. Only TFAHs 10a and 10h showed similar cell toxicity. The less toxic derivatives at $1000 \mu \mathrm{m}$ were $10 \mathrm{n}$ and $10 \mathrm{~m}$, bearing both an octamethylene linker, and a 2'naphthyl or a benzyl group, respectively, (1.72-fold less toxic than tacrine). The most toxic was compound 10i bearing a 2'naphthyl group as $\mathrm{R}^{2}$, and a hexamethylene linker. Among tacrine hybrids 10a-e, bearing a 2'-chloro-6'-methylphenyl group, the less toxic compound 10a (1.47-fold less toxic than tacrine at $1000 \mu \mathrm{m})$ has a pentamethylene linker, but toxicity increased going to TFAH with $n=6$ and $n=7$, and decreased in compound $10 \mathrm{e}$ with a nonamethylene linker. A similar trend was also 
observed in TFAHs 10f-h bearing a benzyl as $R^{2}$ with the less toxic $\mathbf{1 0 h}$ (1.64-fold than tacrine), and in 10i-k a 2'-naphthyl as $\mathrm{R}^{2}$, the longer linker, the lesser toxic remained.<smiles>[R]c1ccc2nc3c(c(NC=N)c2c1)CCCC3</smiles>

$$
8 \mathbf{a} \mathrm{R}^{\prime}=\mathrm{H}
$$
$8 \mathbf{b} \mathrm{R}^{\prime}=\mathrm{OMe}$

$$
\begin{aligned}
& \text { 9a } n=5, R^{1}=H \\
& \text { 9b } n=6, R^{1}=H \\
& \text { 9c } n=7, R^{1}=H \\
& \text { 9d } n=8, R^{1}=H \\
& \text { 9e } n=9, R^{1}=H \\
& \text { 9f } n=8, R^{1}=O M e
\end{aligned}
$$<smiles>[R]NC(=O)CN(C)C(=O)/C=C/c1ccc(O)c(OC)c1</smiles>

Scheme 1. Synthesis of TFAHs 10a-n. Reagents, conditions and range yields. (a) $\mathrm{NH}_{2}\left(\mathrm{CH}_{2}\right)_{n} \mathrm{NH}_{2}$ (3.0 equiv), 1-pentanol, reflux, $18 \mathrm{~h} \quad(54-66 \%)$; (b) Formaldehyde, ferulic acid, isocyanides (benzylisocyanide, 2-chloro-6methylphenyl isocyanide, 2-naphthyl isocyanide), $\mathrm{MeOH} / \mathrm{CH}_{2} \mathrm{Cl}_{2}(3: 1, \mathrm{v} / \mathrm{v})$, rt, $24 \mathrm{~h}(16-48 \%)$.

As final consideration, the type of substituent at the glycine fragment seems to influence the extent of the toxicity on HepG2 cells. Indeed, very interestingly, comparing the toxicity of hybrids with the same length of the linker, and different $R^{2}$, the compounds bearing the benzyl group [10f $(n=6), 10 \mathrm{~g}(\mathrm{n}=7)$, 10h $(n=8)$ ] were always less toxic than their analogues bearing 2'-naphtyl and 2'-chloro-6'-methylphenyl group.

Neuroprotective capacity of TFAHs 10a-n

The neuroprotective capacity of the five least hepatotoxic compounds $10 \mathrm{a}, 10 \mathrm{e}, 10 \mathrm{~h}, 10 \mathrm{~m}$ and $10 \mathrm{n}$ were tested for their ability to prevent the human neuroblastoma cell line SH-SY5Y from cell death induced by three toxicity models : (i) $A \beta$ peptides $\left(\mathrm{A} \beta_{1-40}\right.$ and $\left.\mathrm{A} \beta_{1-42}\right)$ which are implicated in apoptosis-related signaling pathways and ROS production, ${ }^{[39]}$ (ii) hydrogen peroxide $\left(\mathrm{H}_{2} \mathrm{O}_{2}\right)$ for the generation of exogenous free radicals and (iii) the mixture of oligomycin A plus rotenone $(\mathrm{O} / \mathrm{R})$, two mitochondrial respiratory chain blockers, which produce mitochondrial ROS by respectively inhibiting complex $\mathrm{V}$ and I of the mitochondrial electron transport chain. Thus, compounds able to halt or hamper these toxic insults may be considered as neuroprotectants. ${ }^{[40]}$ However, prior to the evaluation of the neuroprotective capacity, direct cell toxicity of the selected TFAHs was investigated at 1, 3 and $10 \mu \mathrm{m}$. In these experiments, cell viability was measured by using the MTT assay. ${ }^{[38]}$ As shown in table 2, TFAH 10a and 10n are not toxic at all tested concentrations, whereas $10 \mathrm{e}, 10 \mathrm{~h}, 10 \mathrm{~m}$ show significant and high toxicity at 3 and $10 \mu \mathrm{m}$, respectively. At $1 \mu \mathrm{m}, \mathbf{1 0 h}$ and $10 \mathrm{~m}$ remains not toxic at $1 \mu \mathrm{m}$, but show significant and high toxicity at 3 and $10 \mu \mathrm{m}$, respectively. Consequently, cell assays on neuroprotection were carried out at 0.3 and $1 \mu \mathrm{m}$ for $10 \mathrm{a}, 10 \mathrm{e}$ and $10 \mathrm{~h}$, at $1 \mu \mathrm{m}$ for $10 \mathrm{~m}$ and at 1 and $3 \mu \mathrm{m}$ for $10 \mathrm{n}$. TFAH $10 \mathrm{~m}$ showed poor neuroprotection against $\mathrm{H}_{2} \mathrm{O}_{2}$ and $\mathrm{O} / \mathrm{R}$, but displayed a very high and significant neuroprotection against the $\mathrm{A} \beta_{1-42}$ insult and a moderate effect against $\mathrm{A} \beta_{1-40}$ (Table 3 ). Interestingly, at the same concentration, 10n showed an opposite, but quantitatively similar, behavior on $\mathrm{A} \beta$-related cell toxicity, showing in addition a moderately significant neuroprotection against $\mathrm{H}_{2} \mathrm{O}_{2}$ and $\mathrm{O} / \mathrm{R}$. However, at $3 \mu \mathrm{m}$, the neuroprotection given by compound 10n against $\mathrm{H}_{2} \mathrm{O}_{2}$ and $\mathrm{O} / \mathrm{R}$ is drastically reduced, while concerning $\mathrm{A} \beta$-induced cell toxicity, a reversed trend is observed, being a more effective but still moderate, neuroprotective agent against cell toxicity induced by $\mathrm{A} \beta_{1-42}$. Very interesting, the overall results obtained for TFAHs $10 \mathrm{a}, 10 \mathrm{e}$ and $10 \mathrm{~h}$ are better than $10 \mathrm{n}$ at $1 \mu \mathrm{m}$. Indeed, those compounds display almost the same moderate neuroprotection against $\mathrm{O} / \mathrm{R}$ and significant to higher neuroprotection against $\mathrm{H}_{2} \mathrm{O}_{2}$ and cell toxicity induced by $A \beta_{1-42}$. On the other hand at 0.3 $\mu \mathrm{M}$ the neuroprotective effect is reduced against $\mathrm{A} \beta_{1-42}$ but is increased for 10e and 10h against O/R.

\section{Inhibition of EeAChE/eqBuChE}

In the first exploratory experiments, we used the cheap and easily available EeAChE and eqBuChE, using tacrine as reference, and the Ellman protocol for the determination of the inhibitory potency. ${ }^{[41]}$

As shown in table 4, the less hepatotoxic 7-MEOTA derivatives 10I-n, showing also interesting neuroprotective properties, were the least potent ChEls among all the TFAHs investigated here. Conversely, the TFAHs $\mathbf{1 0}$ a-k were potent BuChEI, with $\mathrm{IC}_{50}$ values in the nanomolar range, showing selectivities from 115.5 (TFAH 10a) to 1.6 (TFAH 10b). The most potent eqBuChEl being TFAH 10a $\left(\mathrm{IC}_{50}=1.0 \pm 0.2 \mathrm{nM}, 5.1\right.$-fold more potent than tacrine) and the most potent EeAChEl being compound 10c $\left(\mathrm{IC}_{50}=6.2 \pm 0.7 \mathrm{~nm}, 7.2\right.$-fold more potent than tacrine). 


\begin{tabular}{|c|c|c|c|c|c|c|c|}
\hline Compd & $1 \mu \mathrm{m}$ & $3 \mu \mathrm{m}$ & $10 \mu \mathrm{M}$ & $30 \mu \mathrm{m}$ & $100 \mu \mathrm{m}$ & $300 \mu \mathrm{m}$ & $1000 \mu \mathrm{m}$ \\
\hline 10a & $99.3 \pm 1.7^{\mathrm{ns}}$ & $98.9 \pm 1.7^{\mathrm{ns}}$ & $96.4 \pm 1.3^{\text {ns }}$ & $66.1 \pm 1.1^{* * *}$ & $62.9 \pm 1.3^{* * *}$ & $57.9 \pm 2.5^{\star \star *}$ & $50.9 \pm 4.1^{\star * *}$ \\
\hline $10 \mathrm{~b}$ & $99.5 \pm 1.3^{\text {ns }}$ & $87.4 \pm 1.2^{\star *}$ & $85.9 \pm 1.6^{\star \star *}$ & $71.4 \pm 1.1^{\star \star \star}$ & $48.7 \pm 2.0^{* * *}$ & $47.5 \pm 2.0^{\star \star *}$ & $43.2 \pm 1.1^{\star * *}$ \\
\hline $10 c$ & $96.1 \pm 1.1^{\text {ns }}$ & $88.8 \pm 1.3^{\text {ns }}$ & $85.4 \pm 1.8^{*}$ & $82.4 \pm 1.5^{\star \star}$ & $50.5 \pm 2.6^{* * *}$ & $46.8 \pm 4.1^{\star \star *}$ & $43.5 \pm 3.1^{* * *}$ \\
\hline $10 d$ & $98.4 \pm 0.7^{\text {ns }}$ & $96.3 \pm 1.4^{\mathrm{ns}}$ & $88.7 \pm 1.1^{*}$ & $83.8 \pm 1.4^{\star \star \star}$ & $50.2 \pm 2.6^{\star \star \star}$ & $50.6 \pm 2.2^{\star \star \star}$ & $43.3 \pm 1.9^{\star * \star}$ \\
\hline $10 e$ & $100.0 \pm 1.4^{\mathrm{ns}}$ & $97.6 \pm 1.6^{\text {ns }}$ & $95.6 \pm 0.3^{\text {ns }}$ & $71.8 \pm 1.7^{\star * *}$ & $54.2 \pm 1.1^{\text {*** }}$ & $53.5 \pm 0.7^{\star \star \star}$ & $47.2 \pm 2.9^{\star * \star}$ \\
\hline $10 f$ & $97.0 \pm 1.9^{\text {ns }}$ & $92.3 \pm 2.1^{\text {ns }}$ & $91.8 \pm 1.9^{\text {ns }}$ & $92.7 \pm 1.9^{\text {ns }}$ & $63.3 \pm 3.7^{\star \star *}$ & $50.5 \pm 3.8^{* * *}$ & $48.9 \pm 4.4^{\star \star \star}$ \\
\hline $10 \mathrm{~g}$ & $85.3 \pm 2.4^{\mathrm{ns}}$ & $79.0 \pm 3.8^{\star}$ & $76.0 \pm 1.3^{* *}$ & $73.1 \pm 3.9^{\star \star *}$ & $47.2 \pm 3.1^{\star \star \star}$ & $47.0 \pm 3.4^{\star \star \star}$ & $46.3 \pm 2.1^{* \star \star}$ \\
\hline $10 \mathrm{~h}$ & $95.2 \pm 1.5^{\mathrm{ns}}$ & $95.2 \pm 1.7^{\mathrm{ns}}$ & $94.4 \pm 1.7^{\mathrm{ns}}$ & $81.2 \pm 1.0^{* \star \star}$ & $61.8 \pm 0.2^{\star \star *}$ & $60.1 \pm 1.0^{\star \star *}$ & $56.3 \pm 2.0^{* * *}$ \\
\hline $10 i$ & $97.1 \pm 2.6^{\text {ns }}$ & $96.0 \pm 0.4^{\text {ns }}$ & $94.8 \pm 1.6^{\mathrm{ns}}$ & $89.7 \pm 1.9^{\text {ns }}$ & $48.0 \pm 2.8^{\star \star \star}$ & $40.7 \pm 2.3^{\star \star \star}$ & $36.3 \pm 1.9^{* * *}$ \\
\hline 10j & $99.2 \pm 1.4^{\mathrm{ns}}$ & $95.0 \pm 0.8^{\mathrm{ns}}$ & $94.5 \pm 0.3^{\text {ns }}$ & $92.8 \pm 1.2^{\text {ns }}$ & $63.2 \pm 2.9^{* \star *}$ & $44.2 \pm 1.3^{\star \star \star}$ & $39.3 \pm 2.0^{\star * *}$ \\
\hline $10 \mathrm{k}$ & $97.5 \pm 0.3^{\text {ns }}$ & $96.1 \pm 0.6^{\mathrm{ns}}$ & $95.9 \pm 1.4^{\mathrm{ns}}$ & $91.8 \pm 0.9^{\text {ns }}$ & $74.6 \pm 2.8^{\star \star \star}$ & $46.8 \pm 1.4^{\star \star \star}$ & $46.1 \pm 2.3^{* * *}$ \\
\hline 101 & $93.5 \pm 2.4^{\text {ns }}$ & $94.5 \pm 1.5^{\mathrm{ns}}$ & $88.8 \pm 1.6^{\star \star *}$ & $56.6 \pm 0.9^{* * *}$ & $51.4 \pm 1.7^{\star \star \star}$ & $52.4 \pm 1.4^{\star \star *}$ & $50.8 \pm 1.0^{\star \star \star}$ \\
\hline $10 \mathrm{~m}$ & $100.3 \pm 1.1^{\text {ns }}$ & $98.9 \pm 1.8^{\mathrm{ns}}$ & $97.9 \pm 2.8^{\text {ns }}$ & $98.1 \pm 0.9^{\text {ns }}$ & $97.0 \pm 2.7^{\text {ns }}$ & $60.3 \pm 2.9^{* \star *}$ & $59.2 \pm 1.6^{* * *}$ \\
\hline 10n & $98.8 \pm 2.4^{\mathrm{ns}}$ & $97.0 \pm 1.8^{\mathrm{ns}}$ & $92.0 \pm 3.0^{\mathrm{ns}}$ & $94.0 \pm 3.8^{\text {ns }}$ & $83.2 \pm 2.5^{\star}$ & $74.0 \pm 1.4^{\star \star *}$ & $59.4 \pm 4.7^{\star \star *}$ \\
\hline Tacrine & $93.4 \pm 4.7^{\mathrm{ns}}$ & $90 \pm 3.0^{\text {ns }}$ & $88.7 \pm 3.4^{\mathrm{ns}}$ & $81.6 \pm 4.9^{*}$ & $64.3 \pm 4.5^{\star \star \star}$ & $40 \pm 2.2^{\star \star \star *}$ & $34.4 \pm 2.7^{\star \star \star}$ \\
\hline
\end{tabular}

[a] The cell viability was measured as MTT reduction and data were normalized as \% of control. Data are expressed as the means \pm SEM of triplicate of at least three different cultures. All compounds were assayed at increasing concentrations $(1-1000 \mu \mathrm{M})$. ${ }^{* *} P \leq 0.001,{ }^{* *} P \leq 0.01,{ }^{*} P \leq 0.05$ and ns: not significant, with respect to control group. Comparison between tested hybrids and control group was performed by one-way ANOVA followed by the Newman-Keuls post-hoc test. groups. Regarding the influence of the length of the linker on the activity, in the 10a-e hybrids, the best eqBuChE inhibitory activity was found for $n=5$, progressively decreasing from $n=6$ to $n=9$, but remains quite stable around an $\mathrm{IC}_{50}$ values of $2.61 \mathrm{~nm}$. However, for compounds 10f-h, the activity progressively increased from $n=6$ to $\mathrm{n}=\mathbf{8}$, and in the $\mathbf{1 0 i - k}$ series the order of activity, from the most to less potent, was $8>6>7$. Regarding equipotency for EeAChE and eqBuChE, TFAH 10c and 10d were found the most balanced, showing $\mathrm{IC}_{50}$ values around $6.3 \mathrm{~nm}$ and 2.5 $\mathrm{nm}, \quad$ respectively. Overall, considering the toxicity, and ChEI data, we have concluded that the most balanced compounds are 10h, 10a and 10e, in this order, as they are 1.5-, 1.45- and 1.34-fold less toxic than tacrine at $300 \mu \mathrm{m}$, with high eqBuChEl activity, and from potent to moderate EeAChE inhibitory activities. Based on these results, it was quite satisfactory to find that our initial hopes regarding the use of a tacrine-grafted $\alpha$ acylaminocarboxamide backbone in the new TFAHs 10a-k, were fullfiled in terms of synthetic access and ChEs inhibition profiles. Thus, these results allowed us to go further and to analyze the capacity of TFAHs to inhibit human ChEs.

Table 2. SH-SY5Y cell viability in the presence of TFAHs 10a, 10e, 10h, $10 \mathrm{~m}$ and $10 \mathrm{n}{ }^{[\mathrm{a}]}$

\begin{tabular}{|c|c|c|c|}
\hline Compd & $1 \mu \mathrm{m}$ & $3 \mu \mathrm{m}$ & $10 \mu \mathrm{m}$ \\
\hline $10 a$ & $99.9 \pm 6.7^{\text {ns }}$ & $100.2 \pm 5.5^{\mathrm{ns}}$ & $90.8 \pm 1.6^{\mathrm{ns}}$ \\
\hline $10 e$ & $94.6 \pm 5.2^{\text {ns }}$ & $85.5 \pm 5.8^{\text {ns }}$ & $10.0 \pm 3.5^{\star \star \star}$ \\
\hline $10 \mathrm{~h}$ & $91.7 \pm 0.6^{\mathrm{ns}}$ & $81.6 \pm 4.3^{*}$ & $9.9 \pm 2.6^{* * *}$ \\
\hline $10 \mathrm{~m}$ & $99.7 \pm 1.4^{\mathrm{ns}}$ & $79.4 \pm 4.7^{\star \star}$ & $40.1 \pm 1.9^{\star \star \star}$ \\
\hline $10 n$ & $98.9 \pm 0.9^{\text {ns }}$ & $97.5 \pm 1.2^{\text {ns }}$ & $95.1 \pm 1.4^{\mathrm{ns}}$ \\
\hline
\end{tabular}

[a] All compounds were assayed for 24 h. ${ }^{* *} P \leq 0.001,{ }^{* *} P \leq 0.01$. ns: not significant with respect to basal. Data are expressed as the means \pm SEM of triplicate of at least five different cultures.

Regardless the influence of the linker, TFAHs 10a-e bearing the 2'-chloro-6'-methylphenyl group were more potent eqBuChEI than those bearing the benzyl (10f-h) or the 2'-naphthyl (10i-k)

\section{Inhibition of human $\mathrm{AChE} / \mathrm{human} \mathrm{BuChE}$ and kinetic inhibition studies}

As shown in table 4, and in agreement with data obtained on EeAChE, the less toxic 7-MEOTA derivatives 10l-n were the less potent hChEls but better than 7-MEOTA itself (2, Figure 1). TFAHs 10a-k were potent hAChE inhibitors with $I_{50}$ values in the nanomolar range and very potent hBuChE inhibitors, with selectivities ranging from 292.3 (hybrid 10k) to 40.9 (hybrid 10h). The $\mathrm{IC}_{50}$ values for the inhibition of hBuChE were much lower for the same compound for any of the 10a-e (from 0.307 to 0.968 $\mathrm{nm}$ ), 10f-h (from 0.98 to $2.51 \mathrm{~nm}$ ), 10i-k (from 0.260 to $2.48 \mathrm{~nm}$ ) series compared to the eqBuChE inhibition data. The most potent hBuChEl was TFAH 10k $\left(\mathrm{IC}_{50}=0.260 \pm 0.021 \mathrm{nM}, 176.1\right.$ fold more potent than tacrine). For the same length in the linker, TFAHs 10a-e, bearing the 2'-chloro-6'-methylphenyl group, were more potent $\mathrm{hBuChEl}$ than those bearing the benzyl (10f-h) or the 2'-naphthyl (10i-j) groups, except 10k. Regarding the influence of the linker on the activity, 
in TFAHs 10f-h and TFAHs 10i-k hybrids, the hBuChE inhibition was decreasing going from $\mathrm{n}=6$ to $\mathrm{n}=8$. For the TFAHs 10a-e, the best was found for $n=7$ but remaining quite stable in the $\mathrm{IC}_{50}$ values, around $0.32 \mathrm{~nm}$, on going from $\mathrm{n}=7$ to $\mathrm{n}=9$. Concerning inhibition of hAChE, the most potent was compound 10e $\left(\mathrm{IC}_{50}=14.3 \pm 1.1 \mathrm{~nm}, 29.6\right.$-fold more potent than tacrine). The influence of the linker on activity was observed: the $\mathrm{IC}_{50}$ value decreased when going from $n=6$ to $n=9$ for TFAHs $10 \mathrm{~b}-\mathrm{e}$ and from $\mathrm{n}=6$ to $\mathrm{n}=8$ for TFAHs 10f-h and 10i-k. Regarding equipotency for hAChE and hBuChE, TFAH $10 \mathrm{e}$ was found to be the most balanced, showing $\mathrm{IC}_{50}$ values equal to $14.3 \mathrm{~nm}$ and $0.318 \mathrm{~nm}$, respectively for hAChE and hBuChE. However, TFAH 10h is the most balanced of the multipotent hybrids, less toxic than tacrine, able to strongly inhibit human AChE and BuChE.

As general consideration, the mechanism of hAChE inhibition of TFAH $\mathbf{1 0 h}$ has been therefore investigated by building Lineweaver-Burk double reciprocal plots. Lineweaver-Burk plots showed increasing slopes and increasing intercepts with higher inhibitor concentration. The interception of the lines above the $x$-axis (Figure 3 ) indicates that hybrid $10 \mathrm{~h}$ is able to interact with both the free and acylated enzyme and behaves as mixed-type inhibitor of hAChE. The inhibitor dissociation constants $K_{i}$ (dissociation constant for the enzyme-inhibitor complex) and $K_{i}^{\prime}$ (dissociation constant for the enzyme-inhibitor-substrate complex) were estimated and resulted to be 44.1 and 57.2 nm, respectively. Encouraged by these results and in order to investigate the multipotency of
Table 3. Protective effect of TFAHs $10 \mathrm{a}, 10 \mathrm{e}, 10 \mathrm{~h}, 10 \mathrm{~m}$ and $10 \mathrm{n}$ on SH-5YSY cell death induced by A $\beta_{1-40}(30 \mu \mathrm{m}), \mathrm{A} \beta_{1}$ ${ }_{42}(30 \mu \mathrm{m}), \mathrm{H}_{2} \mathrm{O}_{2}(300 \mu \mathrm{M})$, or Oligomycin $\mathrm{A}(10 \mu \mathrm{m}) /$ Rotenone $(30 \mu \mathrm{m}) .^{[\mathrm{a}]}$

\begin{tabular}{|c|c|c|c|c|}
\hline Compd (conc.) & $\mathrm{A} \beta_{1-40}$ & $\mathrm{~A} \beta_{1-42}$ & $\mathrm{H}_{2} \mathrm{O}_{2}$ & $\mathrm{O} / \mathrm{R}$ \\
\hline $10 \mathbf{a}(0.3 \mu \mathrm{M})$ & n.d. & $24.7 \pm 3.6^{*}$ & n.d. & $22.3 \pm 2.9^{* *}$ \\
\hline 10a $(1 \mu \mathrm{m})$ & n.d. & $52.3 \pm 4.2^{* * *}$ & $76.6 \pm 1.5^{\star * *}$ & $30.5 \pm 1.6^{\star *}$ \\
\hline $10 \mathrm{e}(0.3 \mu \mathrm{m})$ & n.d. & $38.1 \pm 2.0^{* *}$ & n.d. & $39.9 \pm 1.4^{* \star *}$ \\
\hline $10 \mathbf{e}(1 \mu \mathrm{M})$ & n.d. & $57.2 \pm 3.9^{\star \star \star}$ & $57.4 \pm 2.8^{\star \star \star}$ & $30.1 \pm 0.7^{\star \star}$ \\
\hline 10h $(0.3 \mu \mathrm{m})$ & n.d. & $16.4 \pm 1.7^{*}$ & n.d. & $37.3 \pm 2.0^{\star \star *}$ \\
\hline 10h $(1 \mu \mathrm{m})$ & n.d. & $65.4 \pm 3.8^{* * *}$ & $56.8 \pm 3.3^{* \star *}$ & $30.6 \pm 0.6^{\star *}$ \\
\hline $10 \mathrm{~m}(1 \mu \mathrm{m})$ & $42.0 \pm 1.4^{*}$ & $80.2 \pm 4.2^{\star \star \star}$ & $2.3 \pm 3.8^{\mathrm{ns}}$ & $15.2 \pm 2.3^{\text {ns }}$ \\
\hline 10n $(1 \mu \mathrm{m})$ & $74.7 \pm 1.2^{\star \star \star}$ & $46.3 \pm 4.9^{*}$ & $52.7 \pm 6.2^{*}$ & $40.0 \pm 2.0^{*}$ \\
\hline 10n (3 $\mu \mathrm{m})$ & $49.8 \pm 2.4^{* *}$ & $59.7 \pm 4.2^{\star *}$ & $19.9 \pm 3.6^{\mathrm{ns}}$ & $21.9 \pm 1.6^{\mathrm{ns}}$ \\
\hline
\end{tabular}

[a] Data are expressed as $\%$ neuroprotection \pm SEM of triplicate of at least four different cultures. ${ }^{* *} P \leq 0.001,{ }^{* *} P \leq 0.01$, ${ }^{\star} P \leq 0.05$, ns: not significant, with respect to control. O/R stands for Oligomycin A/Rotenone, n.d.: not determined.

Table 4. Inhibitions $\left(\mathrm{IC}_{50}, \mathrm{nM}\right)$ of EeAChE, eqBuChE, hAChE, hBuChE by TFAHs 10a-n and reference compounds.

\begin{tabular}{|c|c|c|c|c|c|c|c|}
\hline Compd & $\mathrm{n}$ & $\mathrm{EeAChE}^{[\mathrm{a}]}$ & eqBuChE ${ }^{[a]}$ & Selectivity ${ }^{[b]}$ & $h A C h E^{[d]}$ & $\mathrm{hBuCh} \mathrm{E}^{[\mathrm{d}]}$ & Selectivity ${ }^{[e]}$ \\
\hline $10 a$ & 5 & $115.5 \pm 6.5$ & $1.0 \pm 0.2$ & 115.5 & $52.3 \pm 4.3$ & $0.717 \pm 0.038$ & 72.9 \\
\hline $10 \mathrm{~b}$ & 6 & $5.4 \pm 0.6$ & $3.3 \pm 0.3$ & 1.6 & $102 \pm 6$ & $0.968 \pm 0.055$ & 105.4 \\
\hline $10 c$ & 7 & $6.2 \pm 0.7$ & $2.6 \pm 0.3$ & 2.4 & $70.0 \pm 4.1$ & $0.307 \pm 0.020$ & 228 \\
\hline $10 d$ & 8 & $6.5 \pm 0.1$ & $2.4 \pm 0.1$ & 2.7 & $42.5 \pm 2.9$ & $0.336 \pm 0.028$ & 126.5 \\
\hline $10 e$ & 9 & $26.8 \pm 1.9$ & $3.0 \pm 0.3$ & 9.0 & $14.3 \pm 1.1$ & $0.318 \pm 0.024$ & 45.0 \\
\hline $10 f$ & 6 & $14.6 \pm 2.1$ & $6.0 \pm 1.9$ & 2.4 & $169 \pm 10$ & $2.51 \pm 0.17$ & 67.3 \\
\hline $10 \mathrm{~g}$ & 7 & $14.1 \pm 0.9$ & $2.8 \pm 0.1$ & 5.0 & $71.0 \pm 4.3$ & $1.06 \pm 0.07$ & 67.0 \\
\hline $10 \mathrm{~h}$ & 8 & $7.6 \pm 0.4$ & $2.8 \pm 0.1$ & 2.7 & $40.1 \pm 2.8$ & $0.98 \pm 0.09$ & 40.9 \\
\hline $10 i$ & 6 & $48.4 \pm 0.4$ & $9.1 \pm 1.3$ & 5.3 & $174 \pm 15$ & $2.48 \pm 0.21$ & 70.2 \\
\hline $10 \mathrm{j}$ & 7 & $25.3 \pm 4.8$ & $11.7 \pm 2.2$ & 2.2 & $65.0 \pm 3.3$ & $0.737 \pm 0.071$ & 88.2 \\
\hline $10 k$ & 8 & $14.9 \pm 1$ & $5.9 \pm 0.3$ & 2.5 & $76.5 \pm 6.8$ & $0.260 \pm 0.021$ & 294.2 \\
\hline 101 & 8 & $134.3 \pm 8.1$ & $88.9 \pm 5.7$ & 1.5 & $2119 \pm 136$ & $14.8 \pm 1.1$ & 143.2 \\
\hline $10 \mathrm{~m}$ & 8 & $110.0 \pm 8.4$ & $48.8 \pm 2.3$ & 2.3 & $1326 \pm 43$ & $49.0 \pm 2.6$ & 27.1 \\
\hline $10 n$ & 8 & $51.9 \pm 3.5^{[\mathrm{c}]}$ & $70.5 \pm 1.8^{[\mathrm{c}]}$ & - & $22.2 \pm 1.6^{[c]}$ & $68.2 \pm 3.9$ & - \\
\hline 7-MEOTA & - & n.d. & n.d. & - & $13500 \pm 900$ & $6400 \pm 420$ & 2.1 \\
\hline Tacrine & - & $44.3 \pm 1.5$ & $5.1 \pm 0.2$ & 8.7 & $424 \pm 21$ & $45.8 \pm 3.0$ & 9.3 \\
\hline FA & - & n.d. & n.d. & - & n.a. & n.a. & - \\
\hline
\end{tabular}

[a] Inhibition curves were obtained by nonlinear regression. Ee: electric eel, eq: equine. Each $\mathrm{IC}_{50}$ value is the mean \pm SEM of quadruplicate of at least three different experiments. [b] Ratio $\mathrm{IC}_{50}\left(\right.$ EeAChE)/IC $\mathrm{C}_{50}(\mathrm{eqBuChE})$. [c] Inhibition percentage at $3 \mu \mathrm{m}$. [d] human recombinant $\mathrm{AChE}$ and human serum BuChE were used. Each $\mathrm{IC}_{50}$ value is the mean \pm SEM of at least three different experiments. [e] Ratio $I \mathrm{C}_{50}(\mathrm{hAChE}) / \mathrm{IC}_{50}(\mathrm{hBuChE})$. n.d. stands for not determined. $n . a_{.}=$not active at the highest tested concentration $(0.2 \mathrm{~mm})$. 
the new TFAHs, the antioxidant activity and the ability to inhibit $\mathrm{A} \beta_{1-42}$ self-aggregation were evaluated.

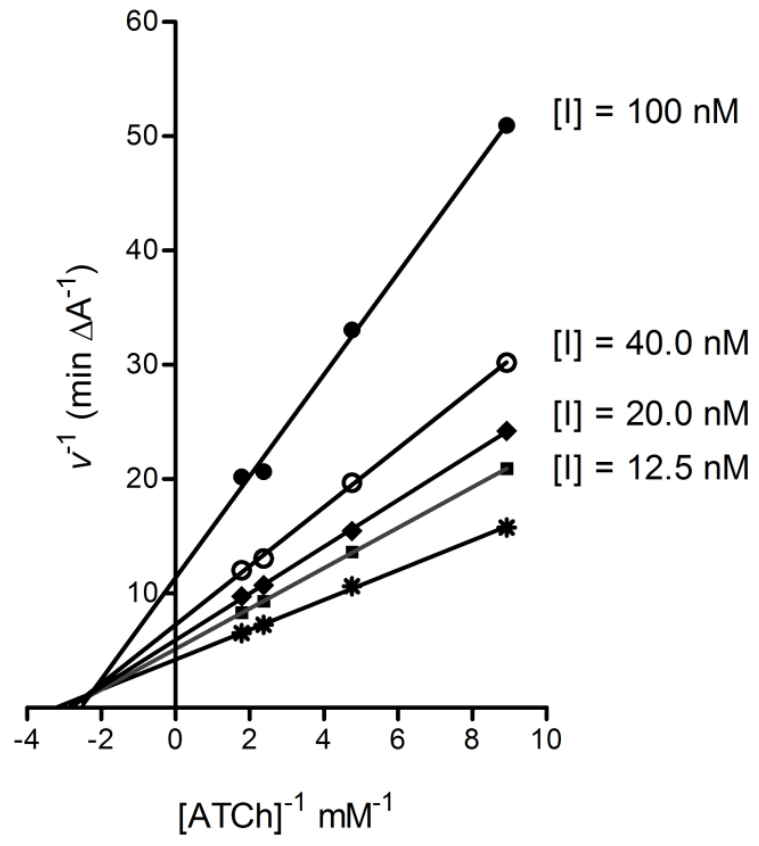

Figure 3. Steady-state inhibition of hAChE hydrolysis of acetylthiocholine (ATCh) by TFAH 10h. Lineweaver-Burk reciprocal plots of initial velocity and substrate concentrations (0.11-0.56 $\mu \mathrm{M})$ are presented. Lines were derived from a weighted leastsquares analysis of data.

\section{Antioxidant activity}

The ability of hybrids 10a-n to reduce the amount of peroxyl radicals was determined by the ORAC-FL (Oxygen Radical Absorbance Capacity by Fluorescence) method, ${ }^{[42,43]}$ using fluorescein $(F L)$ as the fluorescent probe, and Trolox (6-hydroxy2,5,7,8-tetramethyl-chroman-2-carboxylic

acid), as standard compound. Results were expressed as Trolox equivalents ( $\mu \mathrm{mol}$ of trolox/ $\mu \mathrm{mol}$ of tested compound). Ferulic acid was also tested, giving an ORAC value of 3.7 , that fully agreed with the value previously described. ${ }^{[2]}$ As shown in table 5 , all TFAHs derivatives presented a good ability to reduce a peroxyl radical and the ORAC values ranged between 3.43 (TFAH 10i) and 7.74 (TFAH 10b) similarly to ferulic acid (3.7). TFAHs 10i-k, bearing the 2'-naphthyl group were the less potent with nearly the same value. Concerning the 7-MEOTA derivatives (10l-n) with the same length of the linker, the compound $10 \mathrm{~m}$, bearing a benzyl group, showed a higher activity than TFAH $\mathbf{1 0 l}$ and $\mathbf{1 0 n}$.

\section{Inhibition of $\mathbf{A} \boldsymbol{\beta}_{1-42}$ self-aggregation}

The inhibitory activity of hybrids 10a-n against the spontaneous aggregation of $A \beta_{1-42}$ was determined in vitro using a thioflavin $T$ (ThT)-based fluorometric assay. ${ }^{[44]}$ All TFAHs showed interestingly $\mathrm{A} \beta_{1-42}$ antiaggregating activity (Table 5), displaying percentages of inhibition in the range $50.1-80.8 \%$ when tested

\begin{tabular}{|c|c|c|}
\hline Compd & ORAC $^{[\mathrm{a}]}$ & $\mathrm{A} \beta_{1-42}$ self-aggregation $\mathrm{n}^{[\mathrm{b}]}$ \\
\hline $10 a$ & $6.89 \pm 0.08$ & $73.5 \pm 0.2$ \\
\hline $10 \mathrm{~b}$ & $7.74 \pm 0.26$ & $50.1 \pm 2.8$ \\
\hline $10 c$ & $6.40 \pm 0.47$ & $75.0 \pm 1.1$ \\
\hline $10 d$ & $5.29 \pm 0.16$ & $76.7 \pm 0.8$ \\
\hline $10 \mathrm{e}$ & $4.41 \pm 0.04$ & $80.8 \pm 1.5$ \\
\hline $10 f$ & $5.75 \pm 0.32$ & $67.9 \pm 4.2$ \\
\hline $10 \mathrm{~g}$ & $7.04 \pm 0.24$ & $75.0 \pm 1.2$ \\
\hline $10 \mathrm{~h}$ & $6.40 \pm 0.47$ & $69.3 \pm 3.5$ \\
\hline $10 \mathrm{i}$ & $3.43 \pm 0.16$ & $72.0 \pm 0.3$ \\
\hline 10j & $3.57 \pm 0.11$ & $69.0 \pm 1.5$ \\
\hline $10 \mathrm{k}$ & $3.44 \pm 0.09$ & $73.0 \pm 1.5$ \\
\hline 101 & $4.79 \pm 0.39$ & $72.4 \pm 1.3$ \\
\hline $10 \mathrm{~m}$ & $6.47 \pm 0.10$ & $72.1 \pm 3.2$ \\
\hline 10n & $4.29 \pm 0.19$ & $65.6 \pm 0.9$ \\
\hline 7-MEOTA & n.d. & $<5 \%$ \\
\hline Tacrine & $0.2 \pm 0.1^{[24]}$ & $<5 \%$ \\
\hline FA & $3.7 \pm 0.1$ & n.d. \\
\hline
\end{tabular}

[a] Data are expressed as $\mu \mathrm{mol}$ of trolox equivalents/ $\mu \mathrm{mol}$ of tested compound and are shown as means \pm SD. n.d.: not determined.

[a] $\left[\mathrm{A} \beta_{1-42}\right]=50 \mu \mathrm{m}$, [inhibitor] $=50 \mu \mathrm{m}$.

at equimolar concentration with $\mathrm{A} \beta_{1-42}$ ([Inhibitor] $]=\left[\mathrm{A} \beta_{1-42}\right]=50 \mu \mathrm{M}$ ). These data further confirm that these compounds are able to directly inhibit the formation of $\mathrm{A} \beta$ toxic species, as already observed in cell based-assay (Table 3 ). Noteworthy, the reference compounds tacrine and 7-MEOTA were not able to significantly interfere with amyloid aggregation. The most potent $\mathrm{A} \beta_{1-42}$ antiaggregating agent was TFAH $10 \mathrm{e}(80.8 \%)$, but the 7MEOTA derivatives $10 \mathrm{I}$ and $10 \mathrm{~m}$ also showed excellent values around $72 \%$, but no clear SAR could be drawn.

\section{Molecular modeling}

TFAH 10b (see Supporting Information), TFAH 10e (the most active compound against hAChE and the most potent $\mathrm{A} \beta_{1-42}$ antiaggregating agent) and TFAH 10h, the most active of the 10f-h series, being the most balanced multipotent antioxidant hybrid, less toxic than tacrine, able to strongly inhibit hAChE and hBuChE, were used for docking with hAChE (PDB ID: 4EY7) ${ }^{[45]}$ and hBuChE (PDB ID: 4BDS). ${ }^{[46]}$ To note, flexibility and size of these ligands provided several solutions, though a deep 
inspection of the binding modes and energy values led to the following putative binding modes.

The modelling results suggest that TFAHs $10 \mathrm{e}$ and $10 \mathrm{~h}$ are gorged into the catalytic amino acid triad (Ser203, His447 and Glu334) of hAChE oriented along the active-site gorge, extending from the catalytic site at the bottom of the gorge, to the PAS near the mouth of the gorge, via hydrophobic interactions with various aromatic acid residues (Figure 4). Specifically, the predicted binding mode indicates that the tricyclic tetrahydroacridine moiety is engaged in the formation of

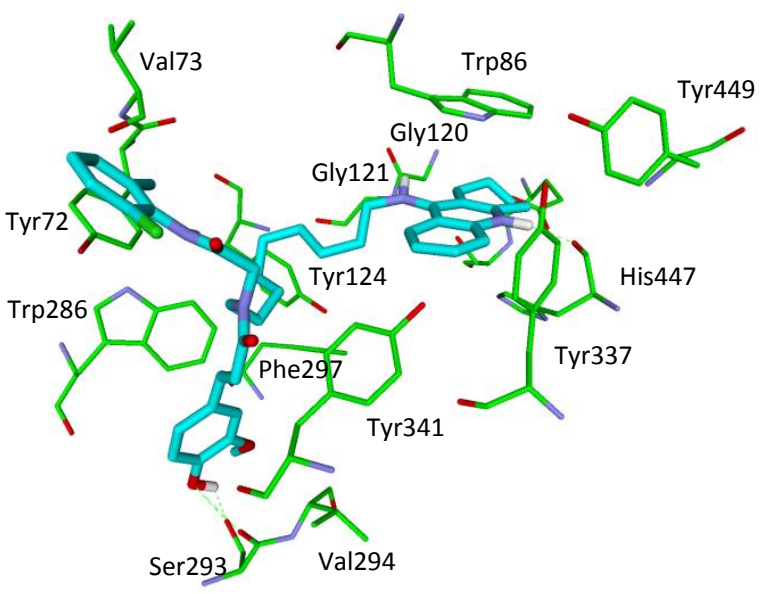

Figure 4. Representation of the binding mode of compound TFAH 10e, as cyan stick, with hAChE (PDB id: 4EY7). The key residues that interact with the molecule are depicted as thin sticks in green.

a characteristic cation- $\pi$ interaction with Trp86 (the cholinebinding site) and T-shaped stacking interactions with Tyr337. The protonated form of tacrine unit gives hydrogen bond with the carbonyl group of His440. Steric clashes with the methoxy substituent at the tacrine unit in compounds 10l-n with the hydrophobic pocket formed by Tyr341 and Tyr337 could explain the decrease of the inhibitory activity. ${ }^{[4]}$ At the mouth of the gorge, the ring of the 2'-chloro-6'-methylphenyl group (or the benzyl group in TFAH 10h) is $\pi$-stacked with Tyr72, a key residue in PAS. The presence of the electron- withdrawing chloro-substituent (TFAH 10e) on the aromatic pendant could lead to reinforcing $\pi-\pi$ interaction, which also seems more effective due to a shorter $R^{2}$ substituent (than those bearing the benzyl moiety as in TFAH 10h).

In addition, the feruloyl moiety of the $\alpha$-acylaminocarboxamide backbone is $\mathrm{H}$-bonded with Ser293 and interacts at PAS with the aromatic core of Trp286 in this predictive binding. It has been estimated that the PAS site was about $20 \AA$ away from the CAS. ${ }^{[48]}$ The extended conformation of TFAH $10 \mathrm{e}$ and TFAH $10 \mathrm{~h}$ has a length of 21.2 and $20.8 \AA$ from the tacrine unit wing to the end of the ferulic acid moiety, respectively, which was enough to cover both the PAS and CAS, leading our compounds acting as dual binding site inhibitors. Finally, the linker fills a hydrophobic pocket delineated by phenyl rings of Tyr121, Phe297, Tyr341, while the amine group is engaged in polar contacts with Gly120 and Gly121.
The inhibitor TFAH 10e was additionally docked with a method previously reported by Darras et al. ${ }^{[49]}$ which takes seven structural water molecules of AChE into account (Figure 5). Thereby, the consistency of the binding mode throughout different docking programs should be explored. This leads to the finding of a theoretical binding mode which can explain interaction with CAS and PAS, too. The presented pose of TFAH $10 \mathrm{e}$ shows the tacrine moiety located in the CAS. The tacrine can be stabilized by a $2.8 \AA$ long hydrogen bond to Ser203. The alkyl linker spans the binding gorge and the amide residues, including the feruloyl, are located at the PAS of AChE (Figure 5). At the entrance of the binding pocket

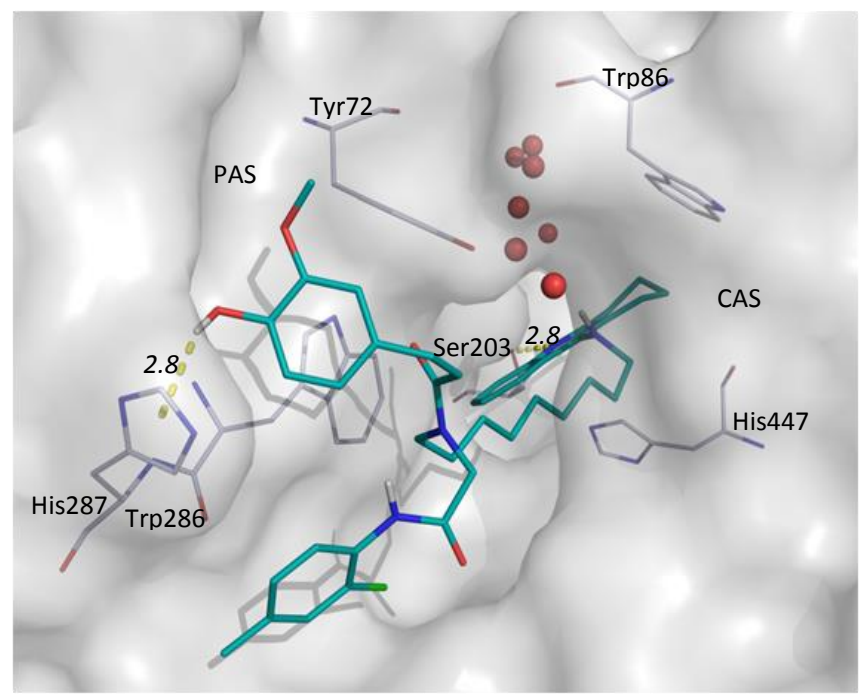

Figure 5. Representation of the binding mode of TFAH 10e (blue) in hAChE (PDB id: 4EY7, surface representation in gray) with seven structural water molecules (red) obtained by the Gold program. Distances are given in italic numbers in $\AA$ and were measured in PyMOL. ${ }^{[50]}$

the feruloyl can be stabilized by forming a $\mathrm{H}-\pi$ interaction of 2.8 $\AA$ with the $\pi$-system of His287. As it becomes visible in the surface representation of the AChE enzyme, the feruloyl part of the $\alpha$-acylaminocarboxamide backbone perfectly fits into the groove at the entrance of the binding site, thus inhibiting the PAS of AChE. This is firstly due to the presence of water molecules which force the tacrine to a different orientation compared to the pose without water. Furthermore, the linker adopts a more linear orientation in the docking pose with water Lastly, in both presented poses, at least one of the aromatic rings supported by the $\alpha$-acylaminocarboxamide chain blocks the PAS. To predict the presence of structural water molecules is not straightforward, thus two possible modes of action - with structural water molecules and without - are presented.

The predictive binding mode for the interaction of the ligand TFAH 10e with the target structure hBuChE is depicted in figure 6 . The tacrine unit of the ligand is $\pi-\pi$ stacked against the aromatic ring of Trp82 and of His 438 and its protonated pyridine nitrogen atom is hydrogen-bonded to carbonyl group of His 438 . Other hydrophobic interactions are formed with Trp430, Tyr440, 
Met437 and Gly439. This disposition in the active site is the same as the tacrine ligand adopts in the enzyme according to the crystallographic data.

The hydrophobic 2'-chloro-6'-methylphenyl moiety was well fitted in a hydrophobic pocket made by Pro285, Thr284, Ala328 and Gly283. In addition, the methoxyphenol is $\pi$-stacked (T-shaped) against the aromatic ring of Phe329, while the hydroxyl group
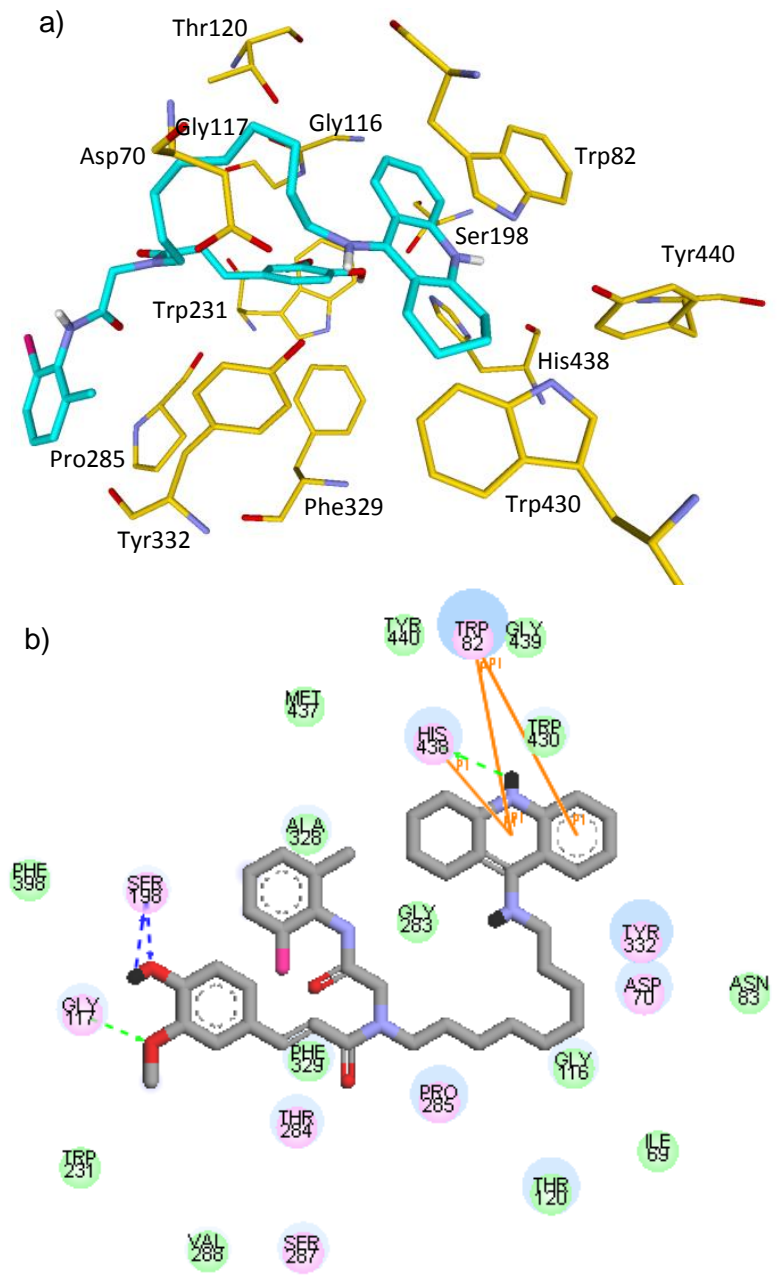

Figure 6. View A: Representation of the binding mode of compound TFAH 10e, as cyan stick, with hBuChE (PDB id: 4BDS). The key residues that interact with the molecule are depicted as thin sticks in orange. View B: $2 \mathrm{D}$ diagram of the ligand-protein interactions (hydrogen bonds, as donor and acceptor, are represented with blue and green dashed lines, respectively).

and the methoxy substituent are H-bonded to Ser198 side chain and to Gly117 main chain, respectively. Additionally, this substituent forms $\mathrm{CH}-\pi$ interactions with Trp231 and other hydrophobic interactions with Phe398 and Val288. Polar interactions are also observed with Thr284, Pro285 and Ser287. The tether link is fitted through hydrophobic and polar interactions with Ile69, Asn83, Gly116 and Thr120, and Asp70 and Tyr332, respectively (Figure 6). For TFAH 10h, a similar binding mode is observed from docking simulations. However, the high flexibility of these ligands allows the formation of stacking interactions involving a different aromatic ring. Thus, the lowest binding energy for TFAH 10h implies stacking interactions of the benzyl moiety with Phe329, as the methoxyphenol group of TFAH 10e, while this one forms sigma$\pi$ interactions with Ser287 and $\mathrm{H}$-bonding, via oxygenated substituents, with Asn289.

\section{In silico ADMET analysis}

Various well known AChEl, such as ensaculine, donepezil, propidium, rivastigmine, and tacrine, have shown slight improvement in cognitive and memory disorders. However, nitrogen containing AChEl drugs have certain side effects and lower central nervous system (CNS) permeability. Thus, the new drugs for AD treatment should have a suitable CNS penetration profile and low side effects. Indeed, one of the most important requirements for a successful CNS drug is to penetrate and reach the therapeutic targets.

To evaluate this aspect, key parameters related to ADMET properties, ${ }^{[51-53]}$ with special emphasis on the requirements of the CNS, were calculated (Table 2S, Supporting Information). The calculated lipophilicity (expressed as logP) and molecular weight (MW) for this series violate the Lipinski's rules for both parameters $(\log \mathrm{P}<5, M W>500) .{ }^{[54]} \mathrm{CNS}$ drugs require more strict rules for a successful penetration to CNS. Thus, the optimal physicochemical properties for a compound targeting the $\mathrm{CNS}^{[55]}$ were rationalized as a $\log \mathrm{P}=2.8$, a $\mathrm{MW}=305 \mathrm{~g} \cdot \mathrm{mol}^{-1}$, a TPSA $=44.8 \AA$ and a hydrogen-bond donor count $=1$. For the series under study, the predicted values fall out the appropriate ranges.

Our estimations of blood-brain barrier (BBB) penetration suggest a moderate absorption to CNS for all the hybrids, but low for TFAHs 10e, 10l and 10n. In this sense, observations made by a team at Pfizer suggested that CNS penetration decreased as MW increased. ${ }^{[56]}$ In addition, TFAHs $\mathbf{1 0 l}$ and 10n present the high values of TPSA. According to the computed values of brain penetration, ${ }^{[57]}$ TFAHs 10a, 10b, 10c and 10f should be the best candidates of the series to act as CNS active compounds.

Another important parameter to be considered for an oral drug is the intestinal permeability. On the basis of the models applied, all the structures show an adequate intestinal (Peff) and apparent Madin-Darby Canine Kidney (MDCK) permeability to be good candidates (Peff>0.1, MDCK $>25$ ), and should be well absorbed compounds (\%HIA). In addition, a middle Caco-2 cell permeability is predicted. ${ }^{[58]}$

Finally, the binding to plasma protein is a parameter which affects drug availability to the target receptor or enzyme. Indeed, the less bound a drug is, the more efficiently it can traverse cell membranes or diffuse to reach the site of action. The percent of drug bound with plasma proteins was estimated and the compounds were predicted to weakly bind to plasma proteins, so they will be available for diffusion or transport across cell membranes and thereby finally interact with the target. As previously observed, ${ }^{[56]}$ plasma protein binding increased with MW. Regarding toxicity issues, in the drug development phase, an early evaluation of a potential for blocking the hERG (human ether-a-go-go related gene) channels is suggested to avoid 
strong side effects in future clinical trials such as QT interval prolongation. According to results of our predictions, all the hybrids show hERG liability. ${ }^{[59]}$ On other hand, none of the hybrids are predicted to induce carcinogenicity in chronic mouse studies. In addition, the models suggest that all molecules, except TFAHs $\mathbf{1 0 m}$ and $\mathbf{1 0 n}$, present hepatotoxicity. ${ }^{[6]}$ To sum up, the structures were predicted to have moderate to low brain penetration profiles, being 10a, 10b, 10c and 10f the hybrids with the best predicted BBB penetration within the TFAHs synthesized in this work.

In order to confirm the virtual BBB predictions, next we carried out the in vitro Blood-Brain Barrier permeation assay of some selected TFAHs.

\section{In vitro Blood-Brain Barrier Permeation Assay}

Many methods have been performed to predict the BBB permeation of investigational drugs. Among them, the parallel artificial membrane permeation assays (PAMPA) have the advantage of predicting passive blood-brain barrier permeation with high success, high throughput, and reproducibility. In this work, brain penetration of TFAHs 10a-n was predicted using the in vitro PAMPA-BBB assay described by $\mathrm{Di}$ et al.. ${ }^{[61]}$ and partially modified by Rodríguez-Franco et al. for assaying molecules with limited water-solubility. ${ }^{[62,16,63]}$ The permeability of hybrids $\left(P_{\mathrm{e}}\right)$ through a lipid extract of porcine brain was determined during 2 hours at room temperature by using PBS: ethanol (70:30) as solvent and results are gathered in table 6 . In the same assay, 11 commercial drugs of known CNS penetration were also tested and their values were compared to reported values, giving a good lineal correlation, $P_{\mathrm{e}}(\exp )=.1.48 P_{\mathrm{e}}$ (bibl. $)+7.14$ $\left(R^{2}=0.93\right)$. From this equation and following the pattern established by $\mathrm{Di}$ et al. for BBB permeation prediction, ${ }^{[61]}$ we can predict compounds as follow: cns + (high BBB permeation) if $P_{\mathrm{e}}$ $\left(10^{-6} \mathrm{~cm} \mathrm{~s}^{-1}\right)>13.0$; cns - (low BBB permeation) if $P_{\mathrm{e}}\left(10^{-6} \mathrm{~cm} \mathrm{~s}\right.$ $\left.{ }^{1}\right)<10.0$; and $\mathrm{cns}+/-$ (uncertain BBB permeation) if $P_{\mathrm{e}}\left(10^{-6}\right.$ $\mathrm{cm} \mathrm{s}^{-1}$ ) is between these values (Table 6). Best results for the CNS permeation were obtained for the 7-MEOTA derivatives, $10 \mathrm{~m}$ and $10 \mathrm{n}$, bearing respectively the benzyl and naphtyl group. Very interestingly, the best predicted BBB penetration TFAHs $10 a, 10 b, 10 c$ and $10 f$ showed no permeability on this assay. In the case of TFAH 10a, and not surprisingly, specific ex-vivo brain penetration study (see Experimental Part) was not observed.

\begin{tabular}{|c|c|c|c|c|c|}
\hline \multirow[b]{3}{*}{ Compd. } & \multirow[b]{3}{*}{$\mathrm{n}$} & \multirow[b]{3}{*}{$\mathrm{R}_{2}$} & \multirow[b]{3}{*}{$\mathrm{R}_{1}$} & BBB Assay $P_{\mathrm{e}}(10$ & $\left.\mathrm{cm} \cdot \mathrm{s}^{-1}\right)$ of \\
\hline & & & & \multicolumn{2}{|c|}{ PAMPA-BBB } \\
\hline & & & & $P_{\mathrm{e}}\left(10^{-6} \mathrm{~cm} \mathrm{~s}^{-1}\right)$ & Prediction \\
\hline $10 a$ & 5 & $2^{\prime}-\mathrm{Cl}-6^{\prime}-\mathrm{MeC}_{6} \mathrm{H}_{3}$ & $\mathrm{H}$ & $6.5 \pm 0.3$ & cns - \\
\hline $10 b$ & 6 & $2^{\prime}-\mathrm{Cl}-6^{\prime}-\mathrm{MeC}_{6} \mathrm{H}_{3}$ & $\mathrm{H}$ & $6.1 \pm 0.2$ & cns - \\
\hline $10 c$ & 7 & $2^{\prime}-\mathrm{Cl}-6^{\prime}-\mathrm{MeC}_{6} \mathrm{H}_{3}$ & $\mathrm{H}$ & $7.6 \pm 0.3$ & cns - \\
\hline $10 d$ & 8 & 2'-Cl-6'- $\mathrm{MeC}_{6} \mathrm{H}_{3}$ & $\mathrm{H}$ & $11.0 \pm 0.4$ & $\mathrm{cns}+/-$ \\
\hline $10 \mathrm{e}$ & 9 & $2^{\prime}-\mathrm{Cl}-6^{\prime}-\mathrm{MeC}_{6} \mathrm{H}_{3}$ & $\mathrm{H}$ & $16.1 \pm 0.8$ & cns + \\
\hline $10 f$ & 6 & $\mathrm{Bn}$ & $\mathrm{H}$ & $6.6 \pm 0.6$ & cns - \\
\hline $10 \mathrm{~g}$ & 7 & $\mathrm{Bn}$ & $\mathrm{H}$ & $7.2 \pm 0.5$ & cns - \\
\hline $10 \mathrm{k}$ & 8 & 2'-Naphtyle & $\mathrm{H}$ & $27.6 \pm 1.4$ & cns + \\
\hline $10 \mathrm{~m}$ & 8 & $\mathrm{Bn}$ & $\mathrm{OMe}$ & $13.2 \pm 0.4$ & cns + \\
\hline $10 n$ & 8 & 2'-Naphtyle & $\mathrm{OMe}$ & $61.5 \pm 4.5$ & cns + \\
\hline
\end{tabular}

[a] Results are the mean \pm SD of three independent experiments.

\section{CONCLUSIONS}

From all the biological and physico-chemical results gathered in this study, we have identified TFAH (E)-3-(4-hydroxy-3methoxyphenyl)- $N$-(8-((7-methoxy-1,2,3,4-tetrahydroacridin-9yl)amino)octyl)- $N$-(2-(naphthalen-2-ylamino)-2-

oxoethyl)acrylamide (10n) as suitable multipotent TFAH for further development. TFAH 10n shows moderate and selective $\mathrm{hBuChE}$ inhibition $\left(\mathrm{IC}_{50}=68.2 \pm 3.9 \mathrm{nM}\right)$, ability to penetrate into the CNS, strong antioxidant power (4.29, ORAC test), inhibition of $A \beta_{1-42}$ self-aggregation (65.6\%) and surpasses by far the other TFAHs in the hepatotoxicity profile $(59.4 \%, 1.72$ less toxic than tacrine, at $1000 \mu \mathrm{m})$, affording good neuroprotection capacity against toxic insults such as $\mathrm{A} \beta_{1-40}, \mathrm{~A} \beta_{1-42}, \mathrm{H}_{2} \mathrm{O}_{2}$, and oligomycin $\mathrm{A} /$ rotenone, on SH-SY5Y cells, at $1 \mu \mathrm{m}$. The power and selectivity of these TFAHs versus BuChE is worth of note as it is very well known that in patients with moderate to severe forms of $A D, A C h E$ levels are decreased, and BuChE activity is elevated, ${ }^{[64]}$ suggesting that $\mathrm{ACh}$ hydrolysis in cholinergic synapses may largely occur via BuChE catalysis. ${ }^{[65]}$ This suggests that specific inhibition of BuChE may be important in raising $A C h$ levels and improving cognition in $A D$ patients with moderate forms of $A D .^{[66]}$

To sum up, we think that the results reported here support and strengthen the interest on the development of new TFAHs derivatives as valuable multipotent drugs for the treatment and prevention of $\mathrm{AD}$. We have also demonstrated and validated the use of the Ugi reaction for the discovery of new MTDLs for AD therapy. Thus, this study provides the basis for the future design of whole new MTDLs libraries having up to five 
pharmacologically relevant scaffolds in one step via the Ugi reaction or its many variations.

\section{EXPERIMENTAL SECTION}

General methods for the synthesis: All reagents were pure analytical grade and used without further purification. All reactions were monitored by TLC using precoated silica gel aluminium plates (Macherey-Nagel) and visualized by UV light. Flash Column chromatographies were carried out using silica gel 60 (70-230 mesh, Macherey-Nagel). ${ }^{1} \mathrm{H}$ and ${ }^{13} \mathrm{C}$ (JMOD sequence) NMR spectra were acquired respectively at $300 \mathrm{MHz}$ and $75 \mathrm{MHz}$ on a Bruker AC300 spectrometer (Bruker BioSpin). Chemical shifts $(\delta)$ are reported in parts per million (ppm) relative to the residual solvent signals and coupling constants $(\mathcal{J})$ are reported in Hertz. The following abbreviations are used: s, singlet; bs, broad singlet; d, doublet; dd, doublet of doublet; $t$, triplet; q, quadruplet; quintuplet, quint.; m, multiplet. Infrared spectra were recorded on a Perkin-Elmer Spectrum 65 spectrophotometer using an Attenuated Total Reflectance device $\left(v\right.$ in $\left.\mathrm{cm}^{-1}\right)$. High resolution mass spectra were obtained at Centre Commun de Spectrométrie de Masse, Lyon, France on a Bruker micrOTOF-Q II spectrometer (Bruker Daltonics) in positive ESI-TOF (electrospray ionization-time of flight). The TFAHs were found to be $\geq 95 \%$ pure by HPLC analysis using a Hitachi Lachrom Elite series instrument equipped with a L2400 Lachrom Elite DAD detector and a Uptisphere ODB column (4.6 $\mathrm{mm} \times 100 \mathrm{~mm}, \varnothing=3 \mu \mathrm{m}$ ). Peaks were detected at $210 \mathrm{~nm}$ and the system was operated at $25^{\circ} \mathrm{C}$ with a flow rate of $2 \mathrm{~mL} / \mathrm{min}$. The mobile phase was an isocratic mixture of acetonitrile and water $(1: 1, \quad \mathrm{v} / \mathrm{v})$ containing $0.1 \% \quad(\mathrm{w} / \mathrm{v})$ monopotassium phosphate.

General procedure for the synthesis of compounds 9a-f: 9Chlorotacrines (9a-f, $1.0 \mathrm{mmol}, 1$ equiv), alkylenediamine (3.0 mmol, 3 equiv) and pentan-1-ol ( $3 \mathrm{~mL})$ were reacted and heated to reflux for $18 \mathrm{~h}$. The reaction was cooled to room temperature, diluted with $\mathrm{CH}_{2} \mathrm{Cl}_{2}(50 \mathrm{~mL})$, and washed with a $10 \%(\mathrm{w} / \mathrm{v})$ aqueous $\mathrm{KOH}$ solution $(2 \times 50 \mathrm{~mL})$ and water $(2 \times 50 \mathrm{~mL})$. The organic layer was dried over $\mathrm{Na}_{2} \mathrm{SO}_{4}$ and concentrated under reduced pressure to afford the crude product which was purified by flash column chromatography $\mathrm{CH}_{2} \mathrm{Cl}_{2} / \mathrm{MeOH}$ /aqueous $30 \%$ $\mathrm{NH}_{3}(7: 3: 0.1, \mathrm{v} / \mathrm{v})$ to afford the products 9a-f. Analytical data of the tacrine linkers 9a-f are in good agreement with previously described data. ${ }^{[33]}$

General procedure for the synthesis of TFAHs 10a-n: A solution of the corresponding $N^{1}$-(1,2,3,4-tetrahydroacridin-9yl)alkane-1,n-diamine 9 a-e or $\quad N^{\prime}$-(7-methoxy-1,2,3,4tetrahydroacridin-9-yl)alkane-1,8-diamine $9 f(1.0 \mathrm{mmol})$ and paraformaldehyde $(1.0 \mathrm{mmol})$ in $\mathrm{MeOH} / \mathrm{CH}_{2} \mathrm{Cl}_{2}(7 \mathrm{~mL}, 3: 1, \mathrm{v} / \mathrm{v})$ was stirred for $1 \mathrm{~h}$ at room temperature. Ferulic acid $(1.0 \mathrm{mmol})$ and the corresponding isocyanide $(1.0 \mathrm{mmol})$ were then added, and the reaction was stirred $24 \mathrm{~h}$ at room temperature. The mixture was subsequently concentrated under reduced pressure to dryness and the crude product was purified by flash column chromatography to afford the corresponding TFAHs. Note regarding the ${ }^{1} \mathrm{H}$ and ${ }^{13} \mathrm{C}$ spectra of TFAHs 10a-n: At $298 \mathrm{~K}$, some Ugi adducts may appear as a mixture of conformers.

(E)-N-(2-((2-Chloro-6-methylphenyl)amino)-2-oxoethyl)-3-(4hydroxy-3-methoxyphenyl)- $N$-(5-((1,2,3,4-tetrahydroacridin9-yl)amino)pentyl)acrylamide $\quad$ (10a): $\quad N^{1}-(1,2,3,4$ tetrahydroacridin-9-yl)pentane-1,5-diamine (9a) (215 mg, 0.76 $\mathrm{mmol}$ ), paraformaldehyde (22 $\mathrm{mg}, 0.76 \mathrm{mmol})$, ferulic acid (147 $\mathrm{mg}, 0.76 \mathrm{mmol}$ ) and 2-chloro-6-methylphenyl isocyanide (115 $\mathrm{mg}, 0.76 \mathrm{mmol}$ ) were reacted in $\mathrm{MeOH} / \mathrm{CH}_{2} \mathrm{Cl}_{2}(7 \mathrm{~mL})$ according to the general procedure for the U-4CR. Flash column chromatography $\mathrm{CH}_{2} \mathrm{Cl}_{2} / \mathrm{MeOH} /$ aqueous $30 \% \quad \mathrm{NH}_{3} \quad(92: 8: 0.1)$ afforded the TFAH 10a (90 mg, 19\%) as an orange foam: $R_{\mathrm{f}}=0.18\left(\mathrm{CH}_{2} \mathrm{Cl}_{2} / \mathrm{MeOH} /\right.$ aqueous $30 \% \mathrm{NH}_{3}$ 92:8:0.1); ${ }^{1} \mathrm{H} \mathrm{NMR}$ (300 MHz, CD $\mathrm{CD}_{3} \mathrm{OD}$ : $\delta=8.09$ and $8.04(\mathrm{~d}, \mathrm{~J}=8.5 \mathrm{~Hz}, 1 \mathrm{H}), 7.74$ $7.71(\mathrm{~m}, 1 \mathrm{H}), 7.54(\mathrm{~d}, J=6.2 \mathrm{~Hz}, 1 \mathrm{H}), 7.49(\mathrm{~d}, J=6.2 \mathrm{~Hz}, 1 \mathrm{H})$, 7.35-7.27 (m, 1H), 7.24-7.21 (m, 1H), 7.15-7.06 (m, 3H), 7.01$6.98(\mathrm{~m}, 1 \mathrm{H}), 6.85(\mathrm{~d}, J=15.2 \mathrm{~Hz}, 1 \mathrm{H}), 6.76(\mathrm{t}, J=8.5 \mathrm{~Hz}, 1 \mathrm{H})$, $4.43(\mathrm{~s}, 1 \mathrm{H}), 4.31(\mathrm{~s}, 1 \mathrm{H}), 3.83$ and $3.77(\mathrm{~m}, 3 \mathrm{H}), 3.64-3.50(\mathrm{~m}$, $4 \mathrm{H}), 2.91(\mathrm{~m}, 2 \mathrm{H}), 2.65-2.62(\mathrm{~m}, 2 \mathrm{H}), 2.25-2.18(\mathrm{~m}, 3 \mathrm{H}), 1.82(\mathrm{~m}$, $4 \mathrm{H}), 1.67-1.60(\mathrm{~m}, 4 \mathrm{H}), 1.48-1.40(\mathrm{~m}, 2 \mathrm{H}) ;{ }^{13} \mathrm{C} \mathrm{NMR}(75 \mathrm{MHz}$, $\left.\mathrm{CD}_{3} \mathrm{OD}\right): \delta=170.5,170.3,170.1,157.9,154.1,150.8,149.6$, $146.5,145.1,140.2,139.9,134.3,133.7,130.6,130.3,129.8$, $129.5,128.4,128.3,128.2,126.7,125.2,125.0,124.8,124.0$, 123.6, 120.7, 116.8, 115.3, 114.9, 112.2, 111.9, 56.6, 52.1, 51.3, 50.7, 33.4, 32.0, 30.9, 30.0, 28.6, 26.0, 25.4, 25.2, 24.0, 23.5, 19.0; HPLC: $t_{\mathrm{R}}=1.84 \mathrm{~min}, 97.8 \%$; HRMS ESI-TOF $[M+\mathrm{H}]^{+} \mathrm{m} / \mathrm{z}$ calcd. for $\mathrm{C}_{37} \mathrm{H}_{41} \mathrm{CIN}_{4} \mathrm{O}_{4}: 641.2889$, found: 641.2881 .

(E)-N-(2-((2-Chloro-6-methylphenyl)amino)-2-oxoethyl)-3-(4-

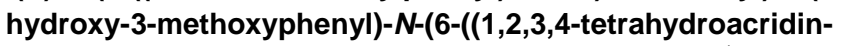
9-yl)amino)hexyl)acrylamide $\quad$ (10b): $\quad N^{1}-(1,2,3,4-$ tetrahydroacridin-9-yl)hexane-1,6-diamine (9b) (206 mg, 0.69 $\mathrm{mmol})$, paraformaldehyde (21 $\mathrm{mg}, 0.69 \mathrm{mmol})$, ferulic acid (134 $\mathrm{mg}, 0.69 \mathrm{mmol}$ ) and 2-chloro-6-methylphenyl isocyanide $(97 \mathrm{mg}$, $0.69 \mathrm{mmol})$ were reacted in $\mathrm{MeOH} / \mathrm{CH}_{2} \mathrm{Cl}_{2}(7 \mathrm{~mL})$ according to the general procedure for the U-4CR. Flash column chromatography $\mathrm{CH}_{2} \mathrm{Cl}_{2} / \mathrm{MeOH} /$ aqueous $30 \% \quad \mathrm{NH}_{3}$ (92:8:0.1) afforded the TFAH $10 \mathrm{~b}(122 \mathrm{mg}, 27 \%)$ as an orange foam: $R_{\mathrm{f}}=0.16\left(\mathrm{CH}_{2} \mathrm{Cl}_{2} / \mathrm{MeOH} /\right.$ aqueous $30 \% \mathrm{NH}_{3}$ 92:8:0.1); ${ }^{1} \mathrm{H} \mathrm{NMR}$ (300 MHz, CD $\left.{ }_{3} \mathrm{OD}\right): \delta=8.05(\mathrm{t}, J=8.0 \mathrm{~Hz}, 1 \mathrm{H}), 7.71(\mathrm{~d}, J=8.0 \mathrm{~Hz}$, $1 \mathrm{H}), 7.51(\mathrm{~d}, J=3.3 \mathrm{~Hz}, 1 \mathrm{H}), 7.46(\mathrm{~d}, J=3.3 \mathrm{~Hz}, 1 \mathrm{H}), 7.35-7.28(\mathrm{~m}$, $1 \mathrm{H}), 7.24-7.21(\mathrm{~m}, 1 \mathrm{H}), 7.12-7.07(\mathrm{~m}, 3 \mathrm{H}), 6.99(\mathrm{t}, J=8.0 \mathrm{~Hz}, 1 \mathrm{H})$, $6.84(\mathrm{~d}, \mathrm{~J}=15.0 \mathrm{~Hz}, 1 \mathrm{H}), 6.77-6.71(\mathrm{~m}, 1 \mathrm{H}), 4.42(\mathrm{~s}, 1 \mathrm{H}), 4.29$ (s, $1 \mathrm{H}), 3.81$ and $3.78(\mathrm{~s}, 3 \mathrm{H}), 3.58-3.49(\mathrm{~m}, 4 \mathrm{H}), 2.90(\mathrm{~m}, 2 \mathrm{H})$, 2.66-2.62 (m, $2 \mathrm{H}), 2.23$ and $2.12(\mathrm{~s}, 3 \mathrm{H}), 1.82(\mathrm{~m}, 4 \mathrm{H}), 1.61(\mathrm{~m}$, $4 \mathrm{H}), 1.35-1.24(\mathrm{~m}, 4 \mathrm{H}) ;{ }^{13} \mathrm{C}$ NMR $\left(75 \mathrm{MHz}, \mathrm{CD}_{3} \mathrm{OD}\right): \delta=170.4$, 170.2 (2C), 170.0, 158.4, 153.9, 150.9, 149.6, 147.1, 145.2, $145.1,140.1,139.8,134.3,133.7,130.3,129.7,129.5,128.4$, $128.3,128.2,127.3,127.2,125.0,124.8,124.7,124.0,123.6$, $121.0,116.8,116.7,116.5,115.3,114.8,112.2,111.8,56.6$, $52.0,51.2,50.8,33.8,32.2,30.2,28.7,27.8,27.5,26.1,24.1$, 23.6, 19.0; IR (ATR): $v_{\max }=3198,2932,2858,1683,1642,1578$, 1511, 1452, $1423 \mathrm{~cm}^{-1}, 1364$; HPLC: $t_{R}=2.15 \mathrm{~min}, 96.7 \%$; HRMS ESI-TOF $[M+\mathrm{H}]^{+} \mathrm{m} / z$ calcd. for $\mathrm{C}_{38} \mathrm{H}_{44} \mathrm{CIN}_{4} \mathrm{O}_{4}: 655.3046$, found: 655.3031. 
(E)-N-(2-((2-Chloro-6-methylphenyl)amino)-2-oxoethyl)-3-(4hydroxy-3-methoxyphenyl)- $N$-(7-((1,2,3,4-tetrahydroacridin9-yl)amino)heptyl)acrylamide $\quad$ (10c): $\quad N^{1}-(1,2,3,4-$ tetrahydroacridin-9-yl)heptane-1,7-diamine (9c) (206 mg, 0.69 $\mathrm{mmol})$, paraformaldehyde $(21 \mathrm{mg}, 0.69 \mathrm{mmol})$, ferulic acid $(134$ $\mathrm{mg}, 0.69 \mathrm{mmol}$ ) and 2-chloro-6-methylphenyl isocyanide $(97 \mathrm{mg}$, $0.69 \mathrm{mmol})$ were reacted in $\mathrm{MeOH} / \mathrm{CH}_{2} \mathrm{Cl}_{2}(7 \mathrm{~mL})$ according to the general procedure for the U-4CR. Flash column chromatography $\mathrm{CH}_{2} \mathrm{Cl}_{2} / \mathrm{MeOH} /$ aqueous $30 \% \quad \mathrm{NH}_{3} \quad(92: 8: 0.1)$ afforded the TFAH 10c (122 $\mathrm{mg}, 27 \%$ ) as a yellow foam: $R_{\mathrm{f}}=0.25\left(\mathrm{CH}_{2} \mathrm{Cl}_{2} / \mathrm{MeOH} /\right.$ aqueous $30 \% \mathrm{NH}_{3}$ 92:8:0.1); ${ }^{1} \mathrm{H}$ NMR (300 MHz, CD $\left.{ }_{3} \mathrm{OD}\right): \delta=8.05$ (t, $\left.J=9.1 \mathrm{~Hz}, 1 \mathrm{H}\right), 7.71$ (d, $J=7.9 \mathrm{~Hz}$, $1 \mathrm{H}), 7.51(\mathrm{~d}, J=4.9 \mathrm{~Hz}, 1 \mathrm{H}), 7.46(\mathrm{~d}, J=4.9 \mathrm{~Hz}, 1 \mathrm{H}), 7.32-7.27(\mathrm{~m}$ $1 \mathrm{H}), 7.22-7.20(\mathrm{~m}, 1 \mathrm{H}), 7.11-7.08(\mathrm{~m}, 3 \mathrm{H}), 6.99(\mathrm{t}, J=9.1 \mathrm{~Hz}, 1 \mathrm{H})$ $6.83(\mathrm{~d}, \mathrm{~J}=15.1 \mathrm{~Hz}, 1 \mathrm{H}), 6.77-6.71(\mathrm{~m}, 1 \mathrm{H}), 4.41(\mathrm{~s}, 1 \mathrm{H}), 4.29(\mathrm{~s}$, $1 \mathrm{H}), 3.79(\mathrm{~s}, 3 \mathrm{H}), 3.57-3.46(\mathrm{~m}, 4 \mathrm{H}), 2.90(\mathrm{~m}, 2 \mathrm{H}), 2.62(\mathrm{~m}, 2 \mathrm{H})$, 2.23 and $2.16(\mathrm{~m}, 3 \mathrm{H}), 1.82(\mathrm{~m}, 4 \mathrm{H}), 1.60-1.57(\mathrm{~m}, 4 \mathrm{H}), 1.30(\mathrm{~m}$, $6 \mathrm{H}) ;{ }^{13} \mathrm{C}$ NMR $\left(75 \mathrm{MHz}, \mathrm{CD}_{3} \mathrm{OD}\right): \delta=170.4,170.2,170.1,170.0$, $158.4,153.7,151.0,149.6,147.2,145.1,140.1,139.8,134.2$, $133.6,130.3,129.7,129.5,128.4,128.3,128.1,127.3,125.0$, $124.7,124.0,123.6,121.0,116.8,116.4,115.2,114.7,112.2$, $111.8,56.6,52.0,51.2,50.8,33.8,32.3,30.2,28.7,27.9,27.7$, $26.1,24.1,23.6,19.0$; IR (ATR): $v_{\max }=3234,2928,2855,1676$, 1642, 1567, 1511, $1421 \mathrm{~cm}^{-1}, 1367$; HPLC: $t_{\mathrm{R}}=2.95 \mathrm{~min}, 99.3 \%$; HRMS ESI-TOF $[M+\mathrm{H}]^{+} \mathrm{m} / z$ calcd. for $\mathrm{C}_{39} \mathrm{H}_{46} \mathrm{CIN}_{4} \mathrm{O}_{4}: 669.3202$, found : 669.3182 .

(E)-N-(2-((2-Chloro-6-methylphenyl)amino)-2-oxoethyl)-3-(4hydroxy-3-methoxyphenyl)- $N$-(8-((1,2,3,4-tetrahydroacridin9-yl)amino)octyl)acrylamide $\quad$ (10d): $\quad N^{1}-(1,2,3,4-$ tetrahydroacridin-9-yl)octane-1,8-diamine (9d) (243 mg, 0.75 $\mathrm{mmol})$, paraformaldehyde (22 $\mathrm{mg}, 0.75 \mathrm{mmol})$, ferulic acid (134 $\mathrm{mg}, 0.75 \mathrm{mmol}$ ) and 2-chloro-6-methylphenyl isocyanide (114 $\mathrm{mg}, 0.75 \mathrm{mmol}$ ) were reacted in $\mathrm{MeOH} / \mathrm{CH}_{2} \mathrm{Cl}_{2}(7 \mathrm{~mL})$ according to the general procedure for the U-4CR. Flash column chromatography $\quad \mathrm{CH}_{2} \mathrm{Cl}_{2} / \mathrm{MeOH} /$ aqueous $\quad 30 \% \quad \mathrm{NH}_{3}$ $\mathrm{CH}_{2} \mathrm{Cl}_{2} / \mathrm{MeOH} /$ aqueous $30 \% \mathrm{NH}_{3}$ (92:8:0.1) afforded the TFAH 10d (138 mg, 27\%) as an orange foam: $R_{\mathrm{f}}=0.30$ $\left(\mathrm{CH}_{2} \mathrm{Cl}_{2} / \mathrm{MeOH}\right.$ /aqueous $30 \% \mathrm{NH}_{3}$ 92:8:0.1); ${ }^{1} \mathrm{H} \mathrm{NMR}(300 \mathrm{MHz}$, $\left.\mathrm{CD}_{3} \mathrm{OD}\right): \delta=8.05(\mathrm{t}, \mathrm{J}=8.0 \mathrm{~Hz}, 1 \mathrm{H}), 7.71(\mathrm{~d}, J=8.0 \mathrm{~Hz}, 1 \mathrm{H}), 7.51$ $(\mathrm{d}, J=6.0 \mathrm{~Hz}, 1 \mathrm{H}), 7.47(\mathrm{~d}, J=6.0 \mathrm{~Hz}, 1 \mathrm{H}), 7.31(\mathrm{t}, J=8.0 \mathrm{~Hz}, 1 \mathrm{H})$, $7.21(\mathrm{~m}, 1 \mathrm{H}), 7.11-7.09(\mathrm{~m}, 3 \mathrm{H}), 6.99(\mathrm{t}, J=9.2 \mathrm{~Hz}, 1 \mathrm{H}), 6.84(\mathrm{~d}$, $\mathrm{J}=15.1 \mathrm{~Hz}, 1 \mathrm{H}), 6.77-6.72(\mathrm{~m}, 1 \mathrm{H}), 4.42(\mathrm{~s}, 1 \mathrm{H}), 4.30(\mathrm{~s}, 1 \mathrm{H})$, $3.80(\mathrm{~s}, 3 \mathrm{H}), 3.59-3.46(\mathrm{~m}, 4 \mathrm{H}), 2.91(\mathrm{~m}, 2 \mathrm{H}), 2.64(\mathrm{~m}, 2 \mathrm{H}), 2.23$ and $2.17(\mathrm{~m}, 3 \mathrm{H}), 1.83(\mathrm{~m}, 4 \mathrm{H}), 1.60-1.56(\mathrm{~m}, 4 \mathrm{H}), 1.26(\mathrm{~m}, 8 \mathrm{H})$; ${ }^{13} \mathrm{C}$ NMR $\left(75 \mathrm{MHz}, \mathrm{CD}_{3} \mathrm{OD}\right): \delta=170.5,170.1,170.0,158.5,153.7$ $151.0,149.6,147.3,145.1,140.1,139.8,134.3,134.1,133.7$, $130.2,129.7,129.5,128.4,128.3,128.1,127.4,125.0,124.7$ $124.0,123.6,121.1,116.9,116.8,116.5,115.3,114.8,112.3$, $111.8,56.6,52.0,51.2,50.8,33.9,32.3,30.3,30.2,28.8,27.9$, 27.6, 26.1, 24.1, 23.7, 19.0; IR (ATR): $v_{\max }=3193,2927,2854$, 1676, 1642, 1578, 1511, 1452, $1365 \mathrm{~cm}^{-1}$; HPLC: $t_{R}=3.63 \mathrm{~min}$, 98.3\%; HRMS ESI-TOF $[M+\mathrm{H}]^{+} \mathrm{m} / z$ calcd. for $\mathrm{C}_{40} \mathrm{H}_{48} \mathrm{CIN}_{4} \mathrm{O}_{4}$ : 683.3359, found: 683.3342 .

(E)-N-(2-((2-Chloro-6-methylphenyl)amino)-2-oxoethyl)-3-(4hydroxy-3-methoxyphenyl)- $N$-(9-((1,2,3,4-tetrahydroacridin9-yl)amino)nonyl)acrylamide $\quad$ (10e): $\quad N^{1}-(1,2,3,4-$ tetrahydroacridin-9-yl)nonane-1,9-diamine (9e) (204 mg, 0.60 $\mathrm{mmol}$ ), paraformaldehyde (18 $\mathrm{mg}, 0.60 \mathrm{mmol})$, ferulic acid (117 $\mathrm{mg}, 0.60 \mathrm{mmol}$ ) and 2-chloro-6-methylphenyl isocyanide (91 $\mathrm{mg}$, $0.60 \mathrm{mmol})$ were reacted in $\mathrm{MeOH} / \mathrm{CH}_{2} \mathrm{Cl}_{2}(7 \mathrm{~mL})$ according to the general procedure for the U-4CR. Flash column chromatography $\mathrm{CH}_{2} \mathrm{Cl}_{2} / \mathrm{MeOH}$ /aqueous $30 \% \quad \mathrm{NH}_{3}$ (92:8:0.1) afforded the TFAH 10e (78 mg, 19\%) as an orange foam: $R_{\mathrm{f}}=0.29\left(\mathrm{CH}_{2} \mathrm{Cl}_{2} / \mathrm{MeOH} /\right.$ aqueous $30 \% \mathrm{NH}_{3}$ 92:8:0.1); ${ }^{1} \mathrm{H} \mathrm{NMR}$ (300 MHz, $\left.\mathrm{CD}_{3} \mathrm{OD}\right): \delta=8.06(\mathrm{t}, \mathrm{J}=8.4 \mathrm{~Hz}, 1 \mathrm{H}), 7.74(\mathrm{~d}, \mathrm{~J}=8.4 \mathrm{~Hz}$, $1 \mathrm{H})$, 7.56-7.49 (m, $2 \mathrm{H}), 7.32(\mathrm{t}, J=8.4 \mathrm{~Hz}, 1 \mathrm{H}), 7.25-7.22(\mathrm{~m}, 1 \mathrm{H})$, 7.15-6.98 (m, 4H), $6.86(\mathrm{~d}, J=15.0 \mathrm{~Hz}, 1 \mathrm{H}), 6.80-6.74(\mathrm{~m}, 1 \mathrm{H})$, $4.45(\mathrm{~s}, 1 \mathrm{H}), 4.34(\mathrm{~s}, 1 \mathrm{H}), 3.83(\mathrm{~s}, 3 \mathrm{H}), 3.62-3.60(\mathrm{~m}, 1 \mathrm{H}), 3.53-$ $3.44(\mathrm{~m}, 3 \mathrm{H}), 2.93(\mathrm{~m}, 2 \mathrm{H}), 2.66(\mathrm{~m}, 2 \mathrm{H}), 2.26$ and $2.20(\mathrm{~m}, 3 \mathrm{H})$, $1.85(\mathrm{~m}, 4 \mathrm{H}), 1.65-1.57(\mathrm{~m}, 4 \mathrm{H}), 1.28-1.20(\mathrm{~m}, 10 \mathrm{H}) ;{ }^{13} \mathrm{C}$ NMR (75 MHz, $\left.\mathrm{CD}_{3} \mathrm{OD}\right): \delta=170.5,170.2,170.0,158.8,153.6,151.3$, $149.7,147.6,145.1,140.1,133.7,130.3,130.1,129.7,129.5$, $128.3,128.0,127.7,124.9,124.7,124.0,123.7,121.2,116.9$, $116.8,116.6,115.2,114.7,112.2,111.8,56.6,52.0,51.2,50.8$, 34.0, 32.4, 30.5, 30.4, 28.0, 27.7, 26.2, 24.2, 23.7, 19.0; HPLC: $t_{R}=4.74 \mathrm{~min}, 96.9 \%$; HRMS ESI-TOF $[M+\mathrm{H}]^{+} \mathrm{m} / \mathrm{z}$ calcd. for $\mathrm{C}_{41} \mathrm{H}_{50} \mathrm{CIN}_{4} \mathrm{O}_{4}$ : 697.3515, found: 697.3491.

\section{(E)-N-(2-(Benzylamino)-2-oxoethyl)-3-(4-hydroxy-3-} methoxyphenyl)- $N-(6-((1,2,3,4-t e t r a h y d r o a c r i d i n-9-$

yl)amino)hexyl)acrylamide (10f): $N^{\prime}$-(1,2,3,4-tetrahydroacridin9-yl)hexane-1,6-diamine (9b) $(200 \quad \mathrm{mg}, 0.67 \quad \mathrm{mmol})$, paraformaldehyde $(20 \mathrm{mg}, 0.67 \mathrm{mmol})$, ferulic acid $(130 \mathrm{mg}$, $0.67 \mathrm{mmol})$ and benzyl isocyanide $(82 \mu \mathrm{L}, 0.67 \mathrm{mmol})$ were reacted in $\mathrm{MeOH} / \mathrm{CH}_{2} \mathrm{Cl}_{2}(7 \mathrm{~mL})$ according to the general procedure for the U-4CR. Flash column chromatography $\mathrm{CH}_{2} \mathrm{Cl}_{2} / \mathrm{MeOH} /$ aqueous $30 \% \mathrm{NH}_{3}$ (92:8:0.1) afforded the TFAH $10 f \quad(139 \mathrm{mg}, \quad 33 \%)$ as a yellow foam: $R_{\mathrm{f}}=0.25$ $\left(\mathrm{CH}_{2} \mathrm{Cl}_{2} / \mathrm{MeOH} /\right.$ aqueous $30 \% \mathrm{NH}_{3}$ 92:8:0.1); ${ }^{1} \mathrm{H} \mathrm{NMR}(300 \mathrm{MHz}$, $\left.\mathrm{CD}_{3} \mathrm{OD}\right): \delta=8.08-8.01(\mathrm{~m}, 1 \mathrm{H}), 7.65(\mathrm{~m}, 1 \mathrm{H}), 7.51(\mathrm{~m}, 1 \mathrm{H}), 7.42$ (d, J=15.0 Hz, $1 \mathrm{H}), 7.31(\mathrm{~m}, 1 \mathrm{H}), 7.20-7.08(\mathrm{~m}, 5 \mathrm{H}), 7.00-6.85$ $(\mathrm{m}, 2 \mathrm{H}), 6.78(\mathrm{~d}, \mathrm{~J}=15.0 \mathrm{~Hz}, 1 \mathrm{H}), 6.69-6.61(\mathrm{~m}, 1 \mathrm{H}), 4.32(\mathrm{~m}$, $2 \mathrm{H}), 4.18(\mathrm{~s}, 1 \mathrm{H}), 4.07(\mathrm{~s}, 1 \mathrm{H}), 3.73$ and $3.70(\mathrm{~m}, 3 \mathrm{H}), 3.49(\mathrm{~m}$, $2 \mathrm{H}), 2.85(\mathrm{~m}, 2 \mathrm{H}), 2.58-2.55(\mathrm{~m}, 2 \mathrm{H}), 1.77(\mathrm{~m}, 4 \mathrm{H}), 1.57-1.47(\mathrm{~m}$, $4 \mathrm{H}), 1.28-1.20(\mathrm{~m}, 6 \mathrm{H}) ;{ }^{13} \mathrm{C} \mathrm{NMR}\left(75 \mathrm{MHz}, \mathrm{CD}_{3} \mathrm{OD}\right): \delta=171.4$, $171.2,169.9,169.8,157.1,156.9,156.8,156.7,154.7,154.5$, $150.6,149.4,145.5,145.4,144.9,140.0,131.1,129.6,128.6$, $128.3,128.2,125.8,125.6,125.3,125.2,125.1,123.7,123.6$, $123.5,120.1,116.7,115.7,115.5,115.3,114.9,112.2,112.0$, $56.6,52.2,51.4,50.7,49.6,44.3,44.2,44.0,32.8,32.1,30.9$, 30.2 , 28.6, 27.7, 27.4, 25.8, 23.8, 23.2; HPLC: $t_{\mathrm{R}}=1.73 \mathrm{~min}$, 97.6\%; HRMS ESI-TOF $[M+\mathrm{H}]^{+} \mathrm{m} / z$ calcd. for $\mathrm{C}_{38} \mathrm{H}_{45} \mathrm{~N}_{4} \mathrm{O}_{4}$ : 621.3435 , found : 621.3435 .

\section{(E)-N-(2-(Benzylamino)-2-oxoethyl)-3-(4-hydroxy-3-} methoxyphenyl)-N-(7-((1,2,3,4-tetrahydroacridin-9yl)amino)heptyl)acrylamide $\quad(\mathbf{1 0 g}): \quad \quad N^{1}-(1,2,3,4-$ tetrahydroacridin-9-yl)heptane-1,7-diamine (9c) (168 mg, 0.54 $\mathrm{mmol}$ ), paraformaldehyde (16 mg, $0.54 \mathrm{mmol})$, ferulic acid (105 $\mathrm{mg}, 0.54 \mathrm{mmol}$ ) and benzyl isocyanide $(66 \mu \mathrm{L}, 0.67 \mathrm{mmol})$ were reacted in $\mathrm{MeOH} / \mathrm{CH}_{2} \mathrm{Cl}_{2}(7 \mathrm{~mL})$ according to the general procedure for the U-4CR. Flash column chromatography $\mathrm{CH}_{2} \mathrm{Cl}_{2} / \mathrm{MeOH} /$ aqueous $30 \% \mathrm{NH}_{3}$ (92:8:0.1) afforded the TFAH $10 \mathrm{~g}(165 \mathrm{mg}, 48 \%)$ as a yellow foam: $R_{\mathrm{f}}=0.30$ $\left(\mathrm{CH}_{2} \mathrm{Cl}_{2} / \mathrm{MeOH} /\right.$ aqueous $30 \% \mathrm{NH}_{3}$ 9:1:0.1); ${ }^{1} \mathrm{H} \mathrm{NMR}(300 \mathrm{MHz}$, 
$\left.\mathrm{CD}_{3} \mathrm{OD}\right): \delta=8.13-8.06(\mathrm{~m}, 1 \mathrm{H}), 7.75-7.73(\mathrm{~m}, 1 \mathrm{H}), 7.57-7.47(\mathrm{~m}$, $2 \mathrm{H}), 7.40-6.96(\mathrm{~m}, 8 \mathrm{H}), 6.89-6.65(\mathrm{~m}, 2 \mathrm{H}), 4.39(\mathrm{~m}, 2 \mathrm{H}), 4.23(\mathrm{~s}$, $1 \mathrm{H}), 4.12(\mathrm{~s}, 1 \mathrm{H}), 3.84$ and $3.80(\mathrm{~m}, 3 \mathrm{H}), 3.55-3.44(\mathrm{~m}, 4 \mathrm{H}), 2.96$ $(\mathrm{m}, 2 \mathrm{H}), 2.72-2.70(\mathrm{~m}, 2 \mathrm{H}), 1.89(\mathrm{~m}, 4 \mathrm{H}), 1.62(\mathrm{~m}, 4 \mathrm{H}), 1.34-$ $1.29(\mathrm{~m}, 6 \mathrm{H}) ;{ }^{13} \mathrm{C}$ NMR $\left(75 \mathrm{MHz}, \mathrm{CD}_{3} \mathrm{OD}\right): \delta=171.4,171.2,169.9$, $169.8,158.2,153.8,153.7,151.3,149.6,146.9,145.0,140.0$ (2C), 139.9, 130.4, 129.6, 128.7, 128.6, $128.3(2 \mathrm{C}), 127.9,127.1$ $125.0,124.7,123.8,123.6,120.8,116.9,116.8,116.3,115.1$, $114.7,112.2,112.1,56.6,52.2,51.4,50.7,44.3(2 \mathrm{C}), 44.2,44.0$, 33.6, 32.2, 30.1, 28.6, 28.3, 27.9, 27.6, 26.0, 24.0, 23.5, 23.4, 23.3; IR (ATR): $v_{\max }=3284,2928,2855,1642,1579,1511,1452$, $1423 \mathrm{~cm}^{-1}$; HPLC: $t_{\mathrm{R}}=1.63 \mathrm{~min}, 95.1 \%$; HRMS ESI-TOF $[M+\mathrm{H}]^{+}$ $\mathrm{m} / \mathrm{z}$ calcd. for $\mathrm{C}_{39} \mathrm{H}_{47} \mathrm{~N}_{4} \mathrm{O}_{4}$ : 635.3592, found: 635.3577.

\section{(E)-N-(2-(Benzylamino)-2-oxoethyl)-3-(4-hydroxy-3- methoxyphenyl)- $\mathrm{N}-(8-((1,2,3,4-t e t r a h y d r o a c r i d i n-9-$}

yl)amino)octyl)acrylamide (10h): $N^{1}$-(1,2,3,4-tetrahydroacridin9-yl)octane-1,8-diamine (9d) (176 $\mathrm{mg}, \quad 0.54 \quad \mathrm{mmol})$, paraformaldehyde (16 mg, $0.54 \mathrm{mmol}$ ), ferulic acid (105 mg, $0.54 \mathrm{mmol}$ ) and benzyl isocyanide $(66 \mu \mathrm{L}, 0.67 \mathrm{mmol})$ were reacted in $\mathrm{MeOH} / \mathrm{CH}_{2} \mathrm{Cl}_{2}(7 \mathrm{~mL})$ according to the general procedure for the U-4CR. Flash column chromatography $\mathrm{CH}_{2} \mathrm{Cl}_{2} / \mathrm{MeOH} /$ aqueous $30 \% \mathrm{NH}_{3}(92: 8: 0.1)$ afforded the TFAH 10h (95 mg, 27\%) as a yellow foam: $R_{\mathrm{f}}=0.31$ $\left(\mathrm{CH}_{2} \mathrm{Cl}_{2} / \mathrm{MeOH}\right.$ /aqueous 30\% $\mathrm{NH}_{3}$ 9:1:0.1); ${ }^{1} \mathrm{H} \mathrm{NMR}(300 \mathrm{MHz}$, $\left.\mathrm{CD}_{3} \mathrm{OD}\right): \delta=8.28-8.20(\mathrm{~m}, 1 \mathrm{H}), 7.71(\mathrm{~m}, 2 \mathrm{H}), 7.49-7.44(\mathrm{~m}, 2 \mathrm{H})$, 7.28-7.10 $(\mathrm{m}, 6 \mathrm{H}), 7.05-7.00(\mathrm{~m}, 1 \mathrm{H}), 6.94-6.84(\mathrm{~m}, 1 \mathrm{H}), 6.74-$ $6.66(\mathrm{~m}, 1 \mathrm{H}), 4.38-4.35(\mathrm{~m}, 2 \mathrm{H}), 4.25(\mathrm{~s}, 1 \mathrm{H}), 4.12(\mathrm{~s}, 1 \mathrm{H}), 3.83-$ $3.71(\mathrm{~m}, 5 \mathrm{H}), 3.58-3.53(\mathrm{~m}, 1 \mathrm{H}), 3.48-3.44(\mathrm{~m}, 1 \mathrm{H}), 3.19(\mathrm{~s}, 1 \mathrm{H})$, $2.95(\mathrm{~m}, 2 \mathrm{H}), 2.66(\mathrm{~m}, 2 \mathrm{H}), 1.90(\mathrm{~m}, 4 \mathrm{H}), 1.74-1.54(\mathrm{~m}, 4 \mathrm{H})$, 1.33 (m, 8H); ${ }^{13} \mathrm{C}$ NMR (75 MHz, $\left.\mathrm{CD}_{3} \mathrm{OD}\right): \delta=171.5,171.3,170.0$ (2C), 158.7, 153.7, 151.0, 149.7, 147.5, 145.0, 140.0, 130.2, $129.8,129.7,128.7,128.3,128.1,127.6,124.9,124.7,123.8$, $123.6,121.1,116.9,116.8,116.6,115.2(2 \mathrm{C}), 114.8,112.2$, $112.1,56.6,52.3,51.4,50.7,44.4,44.2,34.0,32.3,30.3,30.2$, 28.7, 27.9, 27.6, 26.2, 24.1, 23.7, 23.6, 23.5; IR (ATR): $V_{\max }=3233,3059,2927,2854,1638,1584,1514,1452,1427 \mathrm{~cm}^{-}$ 1; HPLC: $t_{\mathrm{R}}=2.71 \mathrm{~min}, 95.7 \%$; HRMS ESI-TOF $[M+\mathrm{H}]^{+} \mathrm{m} / z$ calcd. for $\mathrm{C}_{40} \mathrm{H}_{49} \mathrm{~N}_{4} \mathrm{O}_{4}: 649.3748$, found : 649.3736 .

\section{(E)-3-(4-Hydroxy-3-methoxyphenyl)- $N$-(2-(naphthalen-2-} ylamino)-2-oxoethyl)- $N$-(6-((1,2,3,4-tetrahydroacridin-9yl)amino)hexyl)acrylamide (10i): $N^{1}$-(1,2,3,4-tetrahydroacridin9-yl)hexane-1,6-diamine (9b) $(200 \quad \mathrm{mg}, \quad 0.67 \quad \mathrm{mmol})$, paraformaldehyde $(20 \mathrm{mg}, 0.67 \mathrm{mmol})$, ferulic acid $(130 \mathrm{mg}$, $0.67 \mathrm{mmol}$ ) and naphthyl isocyanide (103 $\mathrm{mg}, 0.67 \mathrm{mmol}$ ) were reacted in $\mathrm{MeOH} / \mathrm{CH}_{2} \mathrm{Cl}_{2}(7 \mathrm{~mL})$ according to the general procedure for the U-4CR. Flash column chromatography $\mathrm{CH}_{2} \mathrm{Cl}_{2} / \mathrm{MeOH}$ /aqueous $30 \% \mathrm{NH}_{3}$ (92:8:0.1) afforded the TFAH 10i (143 mg, 32\%) as a brownish foam: $R_{\mathrm{f}}=0.17$ $\left(\mathrm{CH}_{2} \mathrm{Cl}_{2} / \mathrm{MeOH}\right.$ /aqueous $30 \% \mathrm{NH}_{3}$ 92:8:0.1); ${ }^{1} \mathrm{H} \mathrm{NMR}(300 \mathrm{MHz}$, $\left.\mathrm{CD}_{3} \mathrm{OD}\right): \delta=8.17(\mathrm{~m}, 1 \mathrm{H}), 8.09-8.02(\mathrm{~m}, 1 \mathrm{H}), 7.71-7.64(\mathrm{~m}, 4 \mathrm{H})$, 7.54-7.50 (m, 3H), 7.38-7.32 (m, 3H), 7.09-6.69 (m, 4H), $4.42(\mathrm{~s}$, $1 \mathrm{H}), 4.26(\mathrm{~s}, 1 \mathrm{H}), 3.79(\mathrm{~m}, 2 \mathrm{H}), 3.67-3.60(\mathrm{~m}, 1 \mathrm{H}), 3.52-3.48(\mathrm{~m}$, $2 \mathrm{H}), 2.89(\mathrm{~m}, 2 \mathrm{H}), 2.59(\mathrm{~m}, 2 \mathrm{H}), 1.80(\mathrm{~m}, 4 \mathrm{H}), 1.62-1.56(\mathrm{~m}, 4 \mathrm{H})$, $1.37(\mathrm{~m}, 6 \mathrm{H}) ;{ }^{13} \mathrm{C}$ NMR $\left(75 \mathrm{MHz}, \mathrm{CD}_{3} \mathrm{OD}\right): \delta=170.0,169.8,157.8$ $154.1,150.8,149.5,146.5,145.2,144.9,137.3,135.3,132.3$, $132.2,130.6,129.8,129.7,128.7,128.6,128.3,128.2,127.6$,
$126.6,126.4,126.2,126.1,125.1,125.0,124.8,123.9,123.8$, $121.3,121.2,120.6,118.0,117.9,116.8,116.7,116.2,115.6$, $114.8,112.2,111.7,56.6,52.8,52.3,50.9,49.6,33.4,32.1,32.1$, $30.9,30.3,28.8,27.9,27.7,27.4,25.9,23.9,23.4,23.3$; IR (ATR): $v_{\max }=3269,2928,2855,1690,1640,1583,1561,1503$, 1418, $1361 \mathrm{~cm}^{-1}$; HPLC: $t_{R}=3.31 \mathrm{~min}, 98.1 \%$; HRMS ESI-TOF $[M+\mathrm{H}]^{+} \mathrm{m} / z$ calcd. for $\mathrm{C}_{41} \mathrm{H}_{45} \mathrm{~N}_{4} \mathrm{O}_{4}: 657.3435$, found: 657.3434 .

\section{(E)-3-(4-Hydroxy-3-methoxyphenyl)- $N$-(2-(naphthalen-2-} ylamino)-2-oxoethyl)- $N$-(7-((1,2,3,4-tetrahydroacridin-9yl)amino)heptyl) acrylamide (10j): $\quad N^{1}-(1,2,3,4-$ Tetrahydroacridin-9-yl)heptane-1,7-diamine (9c) (200 mg, 0.64 $\mathrm{mmol}$ ), paraformaldehyde (19 mg, $0.64 \mathrm{mmol})$, ferulic acid (124 $\mathrm{mg}, 0.64 \mathrm{mmol})$ and naphthyl isocyanide $(98 \mathrm{mg}, 0.64 \mathrm{mmol})$ were reacted in $\mathrm{MeOH} / \mathrm{CH}_{2} \mathrm{Cl}_{2}(7 \mathrm{~mL})$ according to the general procedure for the $\mathrm{U}-4 \mathrm{CR}$. Flash column chromatography $\mathrm{CH}_{2} \mathrm{Cl}_{2} / \mathrm{MeOH} /$ aqueous $30 \% \mathrm{NH}_{3}(92: 8: 0.1)$ afforded the TFAH 10j (131 mg, 30\%) as an orange-brownish foam: $R_{\mathrm{f}}=0.19$ $\left(\mathrm{CH}_{2} \mathrm{Cl}_{2} / \mathrm{MeOH}\right.$ /aqueous $30 \% \mathrm{NH}_{3}$ 92:8:0.1); ${ }^{1} \mathrm{H} \mathrm{NMR}(300 \mathrm{MHz}$, $\left.\mathrm{CD}_{3} \mathrm{OD}\right): \delta=8.17(\mathrm{~m}, 1 \mathrm{H}), 8.04(\mathrm{~m}, 1 \mathrm{H}), 7.69(\mathrm{~m}, 4 \mathrm{H}), 7.53-7.50$ $(\mathrm{m}, 3 \mathrm{H}), 7.35-7.32(\mathrm{~m}, 3 \mathrm{H}), 7.09-6.68(\mathrm{~m}, 4 \mathrm{H}), 4.42(\mathrm{~s}, 1 \mathrm{H}), 4.27$ $(\mathrm{s}, 1 \mathrm{H}), 3.80$ and $3.67(\mathrm{~s}, 3 \mathrm{H}), 3.60(\mathrm{~m}, 1 \mathrm{H}), 3.47(\mathrm{~m}, 3 \mathrm{H}), 2.90$ $(\mathrm{m}, 2 \mathrm{H}), 2.61(\mathrm{~m}, 2 \mathrm{H}), 1.82(\mathrm{~m}, 4 \mathrm{H}), 1.62-1.56(\mathrm{~m}, 4 \mathrm{H}), 1.30-$ $1.26(\mathrm{~m}, 6 \mathrm{H}) ;{ }^{13} \mathrm{C}$ NMR $\left(75 \mathrm{MHz}, \mathrm{CD}_{3} \mathrm{OD}\right): \delta=170.0,169.8,157.5$, $154.2,150.8,149.6,146.2,145.2,144.8,144.8,144.7,137.3$, $136.5,135.3,132.2,130.8,130.7,129.7,128.7,128.2,127.6$, $126.6,126.4,126.3,126.2,125.2,125.0,124.6,123.9,123.6$, $121.3,120.4,120.2,118.0,117.9,117.7,116.8,116.4,116.0$, 115.6, 114.8, 113.4, 113.2, 112.3, 111.7, 56.6, 52.8, 52.3, 51.0, 33.3, 32.1, 30.9, 30.2, 29.3, 27.9, 27.7, 25.9, 23.9, 23.4, 23.3; IR (ATR): $v_{\max }=3280,2927,2854,1690,1639,1583,1560,1503$, 1432, $1361 \mathrm{~cm}^{-1}$; HPLC: $t_{\mathrm{R}}=4.02 \mathrm{~min}, 95.6 \%$; HRMS ESI-TOF $[M+\mathrm{H}]^{+} \mathrm{m} / \mathrm{z}$ calcd. for $\mathrm{C}_{42} \mathrm{H}_{47} \mathrm{~N}_{4} \mathrm{O}_{4}: 671.3592$, found: 671.3580 .

(E)-3-(4-Hydroxy-3-methoxyphenyl)-N-(2-(naphthalen-2ylamino)-2-oxoethyl)- $\mathrm{N}$-(8-((1,2,3,4-tetrahydroacridin-9yl)amino)octyl) acrylamide (10k): $\quad N^{1}-(1,2,3,4-$ tetrahydroacridin-9-yl)octane-1,8-diamine (9d) (200 mg, 0.61 $\mathrm{mmol}$ ), paraformaldehyde (18 $\mathrm{mg}, 0.61 \mathrm{mmol}$ ), ferulic acid (118 $\mathrm{mg}, 0.61 \mathrm{mmol})$ and naphthyl isocyanide $(93 \mathrm{mg}, 0.61 \mathrm{mmol})$ were reacted in $\mathrm{MeOH} / \mathrm{CH}_{2} \mathrm{Cl}_{2}(7 \mathrm{~mL})$ according to the general procedure for the $\mathrm{U}-4 \mathrm{CR}$. Flash column chromatography $\mathrm{CH}_{2} \mathrm{Cl}_{2} / \mathrm{MeOH} /$ aqueous $30 \% \mathrm{NH}_{3}$ (92:8:0.1) afforded the TFAH 10k (74 mg, 18\%) as an orange-brownish foam: $R_{\mathrm{f}}=0.32$ $\left(\mathrm{CH}_{2} \mathrm{Cl}_{2} / \mathrm{MeOH} /\right.$ aqueous $30 \% \mathrm{NH}_{3}$ 92:8:0.1); ${ }^{1} \mathrm{H} \mathrm{NMR}(300 \mathrm{MHz}$, $\left.\mathrm{CD}_{3} \mathrm{OD}\right): \delta=8.20-8.18(\mathrm{~m}, 1 \mathrm{H}), 8.08-8.04(\mathrm{~m}, 1 \mathrm{H}), 7.75-7.68(\mathrm{~m}$, $4 \mathrm{H})$, 7.56-7.49 (m, 3H), 7.40-7.34 (m, 3H), 7.14-6.70 (m, $4 \mathrm{H})$, $4.44(\mathrm{~s}, 1 \mathrm{H}), 4.29(\mathrm{~s}, 1 \mathrm{H}), 3.83$ and $3.69(\mathrm{~s}, 3 \mathrm{H}), 3.64-3.59(\mathrm{~m}$, $1 \mathrm{H}), 3.50-3.45(\mathrm{~m}, 3 \mathrm{H}), 2.93(\mathrm{~m}, 2 \mathrm{H}), 2.65(\mathrm{~m}, 2 \mathrm{H}), 1.85(\mathrm{~m}, 4 \mathrm{H})$, 1.65-1.56 (m, 4H), $1.27(\mathrm{~m}, 8 \mathrm{H}) ;{ }^{13} \mathrm{C}$ NMR $\left(75 \mathrm{MHz}, \mathrm{CD}_{3} \mathrm{OD}\right)$ : $\delta=170.1,169.9,154.0,150.8,150.1,149.6,146.9,145.2,144.8$, $135.4,132.3,130.5,129.8,129.7,129.6,128.7,128.3,127.6$, $127.0,126.1,125.1,124.8,123.6,121.3,121.3,120.9,118.2$, $118.0,116.8,116.7,116.4,115.7,114.9,112.3,111.7,56.6$, 52.8, 52.2, 51.0, 33.6, 32.2, 30.3, 28.8, 27.8, 27.6, 26.0, 24.1, 23.6, 23.5; IR (ATR): $v_{\max }=3200,2928,2856,1689,1638,1560$, 1504, 1431, 1352; HPLC: $t_{\mathrm{R}}=5.57 \mathrm{~min}, 98.9 \%$; HRMS ESI-TOF $[M+\mathrm{H}]^{+} \mathrm{m} / z$ calcd. for $\mathrm{C}_{43} \mathrm{H}_{49} \mathrm{~N}_{4} \mathrm{O}_{4}: 685.3748$, found: 685.3744 . 
(E)-N-(2-((2-Chloro-6-methylphenyl)amino)-2-oxoethyl)-3-(4hydroxy-3-methoxyphenyl)-N-(8-((7-methoxy-1,2,3,4tetrahydroacridin-9-yl)amino)octyl)acrylamide (10l): $\quad N^{1}-(7-$ Methoxy-1,2,3,4-tetrahydroacridin-9-yl)octane-1,8-diamine (9f) (202 mg, $0.57 \mathrm{mmol})$, paraformaldehyde (17 mg, $0.57 \mathrm{mmol})$, ferulic acid $(110 \mathrm{mg}, 0.57 \mathrm{mmol})$ and 2-chloro-6-methylphenyl isocyanide ( $86 \mathrm{mg}, 0.57 \mathrm{mmol})$ were reacted in $\mathrm{MeOH} / \mathrm{CH}_{2} \mathrm{Cl}_{2}(7$ $\mathrm{mL}$ ) according to the general procedure for the $\mathrm{U}-4 \mathrm{CR}$. Flash column chromatography with $\mathrm{CH}_{2} \mathrm{Cl}_{2} / \mathrm{MeOH} /$ aqueous $30 \% \mathrm{NH}_{3}$ (92:8:0.1) afforded the TFAH 10I (64 $\mathrm{mg}, 16 \%)$ as a brownish foam: $R_{\mathrm{f}}=0.20\left(\mathrm{CH}_{2} \mathrm{Cl}_{2} / \mathrm{MeOH} /\right.$ aqueous $30 \% \mathrm{NH}_{3}$ 92:8:0.1); ${ }^{1} \mathrm{H}$ NMR (300 MHz, CD $\left.{ }_{3} \mathrm{OD}\right): \delta=7.67(\mathrm{~d}, J=9.0 \mathrm{~Hz}, 1 \mathrm{H}), 7.52$ (d, $J=15.2 \mathrm{~Hz}, 1 \mathrm{H}), 7.36(\mathrm{~d}, J=7.1 \mathrm{~Hz}, 1 \mathrm{H}), 7.28-7.21(\mathrm{~m}, 2 \mathrm{H}), 7.18-$ $7.12(\mathrm{~m}, 3 \mathrm{H}), 7.03(\mathrm{t}, \mathrm{J}=9.0 \mathrm{~Hz}, 1 \mathrm{H}), 6.91-6.81(\mathrm{~m}, 1 \mathrm{H}), 6.76(\mathrm{~d}$, $J=8.1 \mathrm{~Hz}, 1 \mathrm{H}), 4.46-4.32(\mathrm{~m}, 2 \mathrm{H}), 3.88-3.72(\mathrm{~m}, 6 \mathrm{H}), 3.63-3.40$ $(\mathrm{m}, 4 \mathrm{H}), 2.93(\mathrm{~m}, 2 \mathrm{H}), 2.73-2.71(\mathrm{~m}, 2 \mathrm{H}), 2.26$ and $2.20(\mathrm{~s}, 3 \mathrm{H})$, $1.86(\mathrm{~m}, 4 \mathrm{H}), 1.68-1.59(\mathrm{~m}, 4 \mathrm{H}), 1.31-1.26(\mathrm{~m}, 8 \mathrm{H}) ;{ }^{13} \mathrm{C}$ NMR $(75$ $\left.\mathrm{MHz}, \mathrm{CD}_{3} \mathrm{OD}\right): \delta=172.6,170.5,157.8,156.7,152.8,150.7$, $149.6,145.1,143.1,140.1,136.2,134.3,133.7,130.4,130.3$, 129.8, 129.7 (2C), 129.5, 129.2, 129.1, 128.4 (2C), 124.3, 124.0, $123.8,123.6,122.4,122.3,118.1,118.0,116.8,116.7,116.3$, $115.4,115.0,113.2,112.3,111.9,103.2,56.6,56.3,51.6,51.2$, $50.8,33.8,32.4,30.4,30.4,30.2,28.0,27.7,27.6,26.4,24.2$, 23.8, 23.7, 19.0; IR (ATR): $v_{\max } 3234,2928,2855,1679,1625$, $1581,1505,1452,1429 \mathrm{~cm}^{-1}$; HPLC: $t_{\mathrm{R}}=4.10 \mathrm{~min}, 95.6 \%$; HRMS ESI-TOF $[M+\mathrm{H}]^{+} \mathrm{m} / \mathrm{z}$ calcd. for $\mathrm{C}_{41} \mathrm{H}_{50} \mathrm{CIN}_{4} \mathrm{O}_{5}: 713.3464$, found: 713.3471.

\section{(E)-N-(2-(Benzylamino)-2-oxoethyl)-3-(4-hydroxy-3-} methoxyphenyl)- $\mathrm{N}$-(8-((7-methoxy-1,2,3,4-tetrahydroacridin9-yl)amino)octyl)acryl amide (10m): $N^{1}-(7-M e t h o x y-1,2,3,4-$ tetrahydroacridin-9-yl)octane-1,8-diamine (9f) (202 mg, 0.57 $\mathrm{mmol})$, paraformaldehyde (17 $\mathrm{mg}, 0.57 \mathrm{mmol})$, ferulic acid $(110$ $\mathrm{mg}, 0.57 \mathrm{mmol}$ ) and benzyl isocyanide $(70 \mu \mathrm{L}, 0.57 \mathrm{mmol})$ were reacted in $\mathrm{MeOH} / \mathrm{CH}_{2} \mathrm{Cl}_{2}(7 \mathrm{~mL})$ according to the general procedure for the U-4CR. Flash column chromatography with $\mathrm{CH}_{2} \mathrm{Cl}_{2} / \mathrm{MeOH} /$ aqueous $30 \% \mathrm{NH}_{3}$ (92:8:0.1) afforded the TFAH $10 \mathrm{~m}$ (97 mg, 25\%) as a yellow foam: $R_{\mathrm{f}}=0.23$ $\left(\mathrm{CH}_{2} \mathrm{Cl}_{2} / \mathrm{MeOH} /\right.$ aqueous $30 \% \mathrm{NH}_{3}$ 98:2:0.1); ${ }^{1} \mathrm{H} \mathrm{NMR}(300 \mathrm{MHz}$, $\left.\mathrm{CD}_{3} \mathrm{OD}\right): \delta=7.60(\mathrm{~d}, \mathrm{~J}=9.0 \mathrm{~Hz}, 1 \mathrm{H}), 7.46-7.39(\mathrm{~m}, 1 \mathrm{H}), 7.28-7.25$ $(\mathrm{m}, 1 \mathrm{H}), 7.21-7.19(\mathrm{~m}, 2 \mathrm{H}), 7.16-7.11(\mathrm{~m}, 3 \mathrm{H}), 7.07-7.05(\mathrm{~m}, 1 \mathrm{H})$ $7.02(\mathrm{~m}, 1 \mathrm{H}), 6.97-6.93(\mathrm{~m}, 1 \mathrm{H}), 6.88-6.59(\mathrm{~m}, 2 \mathrm{H}), 4.31$ and $4.29(\mathrm{~s}, 2 \mathrm{H}), 4.16(\mathrm{~s}, 1 \mathrm{H}), 4.06(\mathrm{~s}, 1 \mathrm{H}), 3.79-3.68(\mathrm{~m}, 6 \mathrm{H}), 3.46-$ $3.41(\mathrm{~m}, 2 \mathrm{H}), 3.37-3.26(\mathrm{~m}, 2 \mathrm{H}), 2.84(\mathrm{~m}, 2 \mathrm{H}), 2.62-2.60(\mathrm{~m}, 2 \mathrm{H})$ $1.76(\mathrm{~m}, 4 \mathrm{H}), 1.48(\mathrm{~m}, 4 \mathrm{H}), 1.17(\mathrm{~m}, 8 \mathrm{H}) ;{ }^{13} \mathrm{C}$ NMR $(75 \mathrm{MHz}$, $\left.\mathrm{CD}_{3} \mathrm{OD}\right): \delta=171.4,171.2,169.9(2 \mathrm{C}), 157.7,156.6,152.7,151.0$, $150.9,149.6,145.0,143.1,140.0,139.9,129.6,129.1,128.6$, $128.3,(2 \mathrm{C}), 128.1,123.8,123.6,122.3,122.2,117.9,116.9$, $116.8,115.2,114.8,112.2,112.1,103.2,56.6,56.2,52.2,51.4$, $50.7,44.3,44.2,44.0,33.8,32.4,30.4,30.3,30.3,30.2,28.7$, 28.0, 27.6, 26.3, 24.2, 23.8; IR (ATR): $v_{\max }=3282,2927,2854$, 1643, 1581, 1511, 1453, $1428 \mathrm{~cm}^{-1}$; HPLC: $t_{\mathrm{R}}=3.37 \mathrm{~min}, 96.0 \%$; HRMS ESI-TOF $[M+\mathrm{H}]^{+} \mathrm{m} / z$ calcd. for $\mathrm{C}_{41} \mathrm{H}_{51} \mathrm{~N}_{4} \mathrm{O}_{5}: 679.3854$, found : 679.3868 .

(E)-3-(Hydroxy-3-methoxyphenyl)-N-(8((7-methoxy-1,2,3,4tetrahydroacridin-9-yl)amino)octyl)-N-(2-naphthalen-2- ylamino)2-oxoethyl)acrylamide (10n): $N^{1}$-(7-Methoxy-1,2,3,4tetrahydroacridin-9-yl)octane-1,8-diamine (9f) (209 mg, 0.59 $\mathrm{mmol}$ ), paraformaldehyde (18 $\mathrm{mg}, 0.59 \mathrm{mmol})$, ferulic acid (114 $\mathrm{mg}, 0.59 \mathrm{mmol}$ ) and naphthyl isocyanide $(90 \mathrm{mg}, 0.59 \mathrm{mmol})$ were reacted in $\mathrm{MeOH} / \mathrm{CH}_{2} \mathrm{Cl}_{2}(7 \mathrm{~mL})$ according to the general procedure for the U-4CR. Flash column chromatography with $\mathrm{CH}_{2} \mathrm{Cl}_{2} / \mathrm{MeOH} /$ aqueous $30 \% \mathrm{NH}_{3}$ (92:8:0.1) afforded the TFAH 10n (74 mg, 18\%) as a brownish foam: $R_{\mathrm{f}}=0.30$ $\left(\mathrm{CH}_{2} \mathrm{Cl}_{2} / \mathrm{MeOH} /\right.$ aqueous $30 \% \mathrm{NH}_{3}$ 92:8:0.1); ${ }^{1} \mathrm{H} \mathrm{NMR}(300 \mathrm{MHz}$, $\left.\mathrm{CD}_{3} \mathrm{OD}\right): \delta=8.18(\mathrm{~m}, 1 \mathrm{H}), 7.75-7.63(\mathrm{~m}, 4 \mathrm{H}), 7.55-7.48(\mathrm{~m}, 2 \mathrm{H})$, 7.38-7.29 (m, 3H), 7.24-7.18 (m, 1H), 7.11-6.67 (m, 4H), 4.42$4.17(\mathrm{~m}, 2 \mathrm{H}), 3.85-3.67(\mathrm{~m}, 6 \mathrm{H}), 3.61-3.33(\mathrm{~m}, 4 \mathrm{H}), 2.89(\mathrm{~m}, 2 \mathrm{H})$, 2.67-2.65 (m, $2 \mathrm{H}), 1.83(\mathrm{~m}, 4 \mathrm{H}), 1.62-1.55(\mathrm{~m}, 4 \mathrm{H}), 1.32-1.25(\mathrm{~m}$, $8 \mathrm{H}) ;{ }^{13} \mathrm{C}$ NMR $\left(75 \mathrm{MHz}, \mathrm{CD}_{3} \mathrm{OD}\right): \delta=170.0,169.8,157.8,156.3$ (2C), 152.9, 150.8, 149.6, 149.0, 145.2, 144.8, 137.3, 136.5, $135.3,132.2,129.8,129.7,128.9,128.8,128.7,128.6,128.3$, $127.6(2 \mathrm{C}), 126.1,124.6,123.8,123.6,122.3,122.2,121.3$, $121.2,121.1,120.2,118.0,117.9,116.8,116.6,116.2,114.8$, $113.3,113.2,112.3,111.7,103.3,56.6,56.3,52.3,51.7,51.0$, 33.6, 33.6, 32.4, 30.4, 30.3, 28.0, 27.7, 27.6, 26.3, 24.1, 23.7; IR (ATR): $v_{\text {max }}=3286,2928,2854,1690,1627,1583,1560,1503$, 1451, $1430 \mathrm{~cm}^{-1}$; HPLC: $t_{\mathrm{R}}=6.53 \mathrm{~min}, 97.4 \%$; HRMS ESI-TOF $[M+\mathrm{H}]^{+} \mathrm{m} / z$ calcd. for $\mathrm{C}_{44} \mathrm{H}_{51} \mathrm{~N}_{4} \mathrm{O}_{5}: 715.3854$, found: 715.3830 .

\section{Cell culture}

\section{In vitro toxicity of TFAHs 10a-n in HepG2 cells}

The HepG2 cell line was kindly provided by IdiPAZ Institute for Health Research (Madrid, Spain). The cells were cultured in Eagle's minimum essential medium (EMEM) supplemented with 15 nonessential amino acids, $1 \mathrm{mM}$ sodium pyruvate, $10 \%$ heatinactivated fetal bovine serum (FBS), 100 units $/ \mathrm{mL}$ penicillin, and $100 \mu \mathrm{g} / \mathrm{mL}$ streptomycin (reagents from Invitrogen, Madrid, Spain). Cultures were seeded into flasks containing supplemented medium and maintained at $37^{\circ} \mathrm{C}$ in a humidified atmosphere of $5 \% \mathrm{CO}_{2}$ and $95 \%$ air. Culture media were changed every 2 days. Cells were sub-cultured after partial digestion with $0.25 \%$ trypsin-EDTA. For assays, HepG2 cells were subcultured in 96-well plates at a seeding density of $1 \times 10^{5}$ cells per well. When the HepG2 cells reached $80 \%$ confluence, the medium was replaced with fresh medium containing 1-1000 $\mu \mathrm{M}$ compounds or $0.1 \%$ DMSO as a vehicle control. The cell viability was determined by MTT assay. The absorption was measured by a well plate reader at $540 \mathrm{~nm}$. All compounds were dissolved in pure DMSO, but the final DMSO concentration (1$1000 \mu \mathrm{m}$ ) was $0.1 \%$ in culture medium

\section{Effect of TFAHs 10a-n on O/R and $\mathrm{H}_{2} \mathrm{O}_{2}$-induced oxidative} cell damage in SH-SY5Y cells

Human dopaminergic neuroblastoma SH-SY5Y cells were maintained in a 1:1 mixture of Nutrient Mixture F-12 and Eagle's minimum essential medium (EMEM) supplemented with 15 nonessential amino acids, sodium pyruvate $(1 \mathrm{~mm}), 10 \%$ heatinactivated FBS, 100 units $/ \mathrm{ml}$ penicillin, and $100 \mu \mathrm{g} / \mathrm{ml}$ streptomycin. Cultures were seeded into flasks containing supplemented medium and maintained at $37^{\circ} \mathrm{C}$ in a humidified atmosphere of $5 \% \mathrm{CO}_{2}$ and $95 \%$ air. For assays, SH-SY5Y cells were subcultured in 96-well plates at a seeding density of $8 \times 10^{4}$ cells per well for $2 \mathrm{~d}$. Cells were co-incubated with $\mathrm{H}_{2} \mathrm{O}_{2}(300 \mu \mathrm{m})$ 
or oligomycin $A(10 \mu \mathrm{m}) /$ rotenone $(30 \mu \mathrm{m})(\mathrm{O} / \mathrm{R})$ for $24 \mathrm{~h}$ to induce oxidative stress at several concentrations of test compounds in F-12/EMEM with 1\% FBS. A vehicle group containing $0.1 \%$ dimethyl sulfoxide (DMSO) was employed in parallel for each experiment. All SH-SY5Y cells used in this study were used at a low passage number $(<13)$. The cell viability was determined by MTT assay. The absorption was measured by a well plate reader at $540 \mathrm{~nm}$.

Effects of TFAHs $10 \mathrm{a}-\mathrm{n}$ on $A \beta_{1-40}$ and $A \beta_{1-42}$ peptidesinduced neurotoxicity in SH-SY5Y cells

Lyophilized $A \beta_{1-40}$ and $A \beta_{1-42}$ peptides (Abcam, MA, USA) were reconstituted in sterile water at a concentration of $2 \mathrm{~mm}$ and keep at $80{ }^{\circ} \mathrm{C}$ until use. Aliquots were diluted with a culture medium to achieve a final concentration of $30 \mu \mathrm{m}$ and then incubated at $37 \stackrel{\circ}{\circ} \mathrm{C}$ for $72 \mathrm{~h}$ to form aggregated amyloid. For assays, SH-SY5Y cells were sub-cultured into a 96 well plate for $24 \mathrm{~h}$. Then, the cells were incubated with $\mathrm{A} \beta_{1-40}$ and $\mathrm{A} \beta_{1-42}$ peptides $(30 \mu \mathrm{M})$ without or with various concentrations of the test compound for $24 \mathrm{~h}$. Cell viability was determined by staining the cells with $0.5 \mathrm{mg} / \mathrm{ml}$ of MTT assay. The absorption was measured by a well plate reader at $540 \mathrm{~nm}$.

\section{Measurement of cell viability}

MTT reduction was performed as described ${ }^{[38]}$ for the HepG2 cell line. This assay is based on the ability of the mitochondrial enzyme succinate dehydrogenase to convert the yellow watersoluble tetrazolium salt (MTT) into formazan crystals in metabolically active cells. Briefly, $50 \mu \mathrm{L}$ of the MTT labeling reagent, at a final concentration of $0.5 \mathrm{mg} / \mathrm{ml}$, was added. After incubation for $2 \mathrm{~h}$, in a humidified incubator at $37^{\circ} \mathrm{C}$ with $5 \%$ $\mathrm{CO}_{2}$ and $95 \%$ air $(\mathrm{v} / \mathrm{v})$, the supernatant was removed, the obtained purple formazan product was re-suspended in $100 \mu \mathrm{L}$ of Dimethyl Sulfoxide (DMSO). Colorimetric determination of MTT reduction was measured in an ELISA microplate reader at $540 \mathrm{~nm}$. Control cells treated with EMEM were taken as $100 \%$ viability.

\section{Inhibition of cholinesterases}

\section{Inhibition of EeAChE and eqBuChE}

Inhibitory activity assessment of the TFAHs on ChEs was performed following the spectrophotometric method of Ellman ${ }^{[41]}$ using purified AChE from Electrophorus electricus (Type V-S, Sigma-Aldrich) or BuChE from horse serum (lyophilized powder, Sigma-Aldrich). Enzymes were first dissolved in $0.1 \mathrm{~m}$ phosphate buffer $(\mathrm{pH}=8.0)$ and then aliquoted in small vials. Compounds stock solutions in DMSO $(10 \mathrm{~mm})$ were further diluted with DMSO to prepare nine serial dilutions of each compound. The reaction occurs in a final volume of $3 \mathrm{~mL}$ of a $0.1 \mathrm{M}$ phosphatebuffered solution at $\mathrm{pH}=8.0$, containing 5,5'-dithiobis-2nitrobenzoic acid (DTNB, $2625 \mu \mathrm{L}, 0.35 \mathrm{~mm}$, final concentration), EeAChE $(29 \mu \mathrm{L}, 0.035 \mathrm{U} / \mathrm{mL}$, final concentration) or eqBuChE (60 $\mu \mathrm{L}, 0.05 \mathrm{U} / \mathrm{mL}$, final concentration), tested compound ( $3 \mu \mathrm{L}$, $0.001-1000 \mathrm{~nm}$, final concentrations) and $1 \% \mathrm{w} / \mathrm{v}$ Bovine Albumin Serum phosphate-buffered $(\mathrm{pH}=8.0)$ solution (BSA, 60 $\mu \mathrm{L})$. Inhibition curves were built by pre-incubating this blend at room temperature with nine concentrations of each compound for $10 \mathrm{~min}$. A control with no compound was always present to determine the percent of enzymatic activity. After this pre- incubation period, acetylthiocholine iodide $(105 \mu \mathrm{L}, 0.35 \mathrm{~mm}$, final concentration) or butyrylthiocholine iodide $(150 \mu \mathrm{L}, 0.5 \mathrm{~mm}$, final concentration) was added, allowing 15 min of additional incubation time, where the DTNB produces the yellow anion 5thio-2-nitrobenzoic acid as an indicator of enzymatic activity. After $15 \mathrm{~min}$, absorbances were measured at $412 \mathrm{~nm}$ in a spectrophotometer plate reader (iEMS Reader MF, Labsystems). Color generation would be reduced as the compound inhibits the enzymes. $\quad \mathrm{IC}_{50}$ values were calculated graphically at the concentration of compound that decreases $50 \%$ of the enzymatic activity by using a nonlinear regression method (four parameter logistic method). Data are expressed as means \pm SEM of at least three different experiments in quadruplicate.

\section{Inhibition of hAChE and hBuChE}

The capacity of the new derivatives to inhibit cholinesterases activity was assessed using the Ellman's method. ${ }^{[41]}$ Initial rate assays were performed at $37{ }^{\circ} \mathrm{C}$ with a Jasco V-530 double beam Spectrophotometer by following the rate of increase in the absorbance at $412 \mathrm{~nm}$ for $210 \mathrm{~s}$. AChE stock solution was prepared by dissolving human recombinant AChE (E.C.3.1.1.7) lyophilized powder (Sigma, Italy) in $0.1 \mathrm{M}$ phosphate buffer $(\mathrm{pH}=$ 8.0) containing Triton X-100 $0.1 \%$. Stock solution of BuChE (E.C. 3.1.1.8) from human serum (Sigma, Italy) was prepared by dissolving the lyophilized powder in an aqueous solution of gelatine $0.1 \%$. The final assay solution consisted of a $0.1 \mathrm{~m}$ phosphate buffer $(\mathrm{pH}=8.0)$, with the addition of $340 \mu \mathrm{m} \mathrm{5,5}$ dithio-bis(2-nitrobenzoic acid), 0.02 unit $/ \mathrm{mL}$ of human recombinant AChE, or BuChE from human serum and $550 \mu \mathrm{m}$ of substrate (acetylthiocholine iodide, ATCh or butyrylthiocholine iodide, BTCh, respectively). Stock solutions of tested compounds were prepared in methanol. Five different concentrations of inhibitor were selected in order to obtain inhibition of the enzymatic activity comprised between $20 \%$ and $80 \%$. Assays were carried out with a blank containing all components except AChE or BuChE in order to account for the non-enzymatic reaction. Assay solutions (with and without inhibitor) were preincubated for $20 \mathrm{~min}$ at $37^{\circ} \mathrm{C}$ before the addition of substrate. The reaction rates were compared and the percent inhibition due to the presence of increasing concentrations of inhibitor was calculated. Each concentration was analyzed in duplicate, and $\mathrm{IC}_{50}$ values were determined graphically from log concentration-\% inhibition curves (GraphPad Prism 4.03 software, GraphPad Software Inc.).

\section{Oxygen Radical Absorbance Capacity Assay}

The radical scavenging capacity of the TFAHs was determined by the ORAC-FL method using fluorescein as a fluorescent probe. ${ }^{[42,43]} \quad( \pm)$-6-Hydroxy-2,5,7,8-tetramethylchromane-2carboxylic acid (Trolox), fluorescein (FL) and 2,2'azobis(amidinopropane) dihydrochloride (AAPH) were purchased from Sigma-Aldrich. A Varioskan Flash plate reader with built-in injectors (Thermo Scientific) was used. The reaction was carried out at $37^{\circ} \mathrm{C}$ in $75 \mathrm{~mm}$ phosphate buffer $(\mathrm{pH}=7.4)$, and the final volume reaction mixture was $200 \mu \mathrm{L}$. The tested compounds and Trolox standard were dissolved in DMSO to 10 $\mathrm{mm}$ and further diluted in $75 \mathrm{~mm}$ phosphate buffer $(\mathrm{pH}=7.4)$. The final concentrations were $0.1-1 \mu \mathrm{m}$ for the tested compounds and 1-8 $\mu \mathrm{m}$ for Trolox standard. The blank was composed of $120 \mu \mathrm{L}$ 
of $\mathrm{FL}, 60 \mu \mathrm{L}$ of $\mathrm{AAPH}$ and $20 \mu \mathrm{L}$ of phosphate buffer $(\mathrm{pH}=7.4)$ and was added in each assay. In a black 96-well microplate (Nunc), antioxidant $(20 \mu \mathrm{L})$ and fluorescein (FL, $120 \mu \mathrm{L}$, final concentration of $70 \mathrm{~nm}$ ) were incubated for $15 \mathrm{~min}$ at $37^{\circ} \mathrm{C}$. Then, 2,2'-azobis(amidinopropane) dihydrochloride (AAPH, 60 $\mu \mathrm{L}$, final concentration of $40 \mathrm{~mm}$ ) solution was added rapidly using the built-in injector. The fluorescence was measured every minute for $60 \mathrm{~min}$ at $485 \mathrm{~nm}$ (excitation wavelength) and $535 \mathrm{~nm}$ (emission wavelength). The microplate was automatically shaken prior to each reading. All the reactions were made in triplicate and at least three different assays were performed for each sample. Antioxidant curves (fluorescence versus time) were first normalized to the curve of the blank (without antioxidant) and then, the area under the fluorescence decay curve $(A \cup C)$ was calculated as: $A \cup C=1+\operatorname{sum}\left(f i / f_{0}\right)$, Where $f_{0}$ is the initial fluorescence reading at $0 \mathrm{~min}$ and $\mathrm{fi}$ is the fluorescence value at time $i$.

The net AUC corresponding to a sample was calculated as follows: Net $A \cup C=A \cup C_{\text {antioxidant }}-\mathrm{AUC}_{\text {blank. }}$.

Regression equations were calculated by plotting the net AUC against the antioxidant concentration. The ORAC value was obtained by dividing the slope of the latter curve between the slope of the Trolox curve obtained in the same assay. Final ORAC values were expressed as $\mu \mathrm{mol}$ of Trolox equivalent $/ \mu \mathrm{mol}$ of TFAH. Data are expressed as means $\pm S D$.

\section{Kinetic inhibition studies}

To estimate the mode of inhibition of TFAH 10h, LineweaverBurk double reciprocal plots were constructed at relatively low concentration of substrate $(0.11-0.56 \mu \mathrm{M})$. The plots were assessed by a weighted least square analysis that assumed the variance of $v$ to be a constant percentage of $v$ for the entire data set. Data analysis was performed with GraphPad Prism 4.03 software (GraphPad Software Inc.). Calculation of the inhibitor constant $\left(K_{i}\right)$ value was carried out by re-plotting slopes of lines from the Lineweaver-Burk plot versus the inhibitor concentration and $K_{\mathrm{i}}$ was determined as the intersect on the negative $x$-axis. $K_{i}^{\prime}$ (dissociation constant for the enzyme-substrate-inhibitor complex) value was determined by plotting the apparent $1 / v_{\max }$ versus inhibitor concentration. ${ }^{[67]}$

\section{Inhibition of $\mathbf{A} \beta_{1-42}$ self-aggregation}

1,1,1,3,3,3-Hexafluoro-2-propanol (HFIP) pre-treated $\mathrm{A} \beta_{1-42}$ samples (Bachem $A G$, Switzerland) were resolubilized with a $\mathrm{MeCN} / \mathrm{Na}_{2} \mathrm{CO}_{3} / \mathrm{NaOH}(48.4 / 48.4 / 3.2)$ mixture to have a stable stock solution $\left(\left[\mathrm{A} \beta_{1-42}\right]=500 \mu \mathrm{M}\right) .{ }^{[44]}$ Experiments were performed by incubating the peptide in $10 \mathrm{~mm}$ phosphate buffer $(\mathrm{pH}=8.0)$ containing $10 \mathrm{~mm} \mathrm{NaCl}$, at $30{ }^{\circ} \mathrm{C}$ for $24 \mathrm{~h}$ (final $\mathrm{A} \beta$ concentration $=50 \mu \mathrm{M})$ with and without inhibitor $(50 \mu \mathrm{m})$. The inhibitor was dissolved in methanol and diluted in the assay buffer. Blanks containing inhibitor and ThT were also prepared and evaluated to account for quenching and fluorescence properties. To quantify amyloid fibril formation, the ThT fluorescence method was used. ${ }^{[68,69]}$ After incubation, samples were diluted to a final volume of $2.0 \mathrm{~mL}$ with $50 \mu \mathrm{m}$ glycine$\mathrm{NaOH}$ buffer $(\mathrm{pH}=8.5)$ containing $1.5 \mu \mathrm{m}$ ThT. A 300-secondstime scan of fluorescence intensity was carried out $\left(\lambda_{\text {exc }}=446\right.$ $\mathrm{nm} ; \lambda_{\mathrm{em}}=490 \mathrm{~nm}$ ), and values at plateau were averaged after subtracting the background fluorescence of $1.5 \mu \mathrm{m}$ ThT solution. The fluorescence intensities were compared and the \% inhibition was calculated.

\section{Docking simulations}

The geometry of the ligands were optimized using the ab initio quantum chemistry program Gaussian 09 and the B3LYP/3$21 \mathrm{G}^{*}$ basis set. A set of atom-centred RHF $6-31 \mathrm{G}^{*}$ charges was then obtained by using the RESP methodology. ${ }^{[70]}$ The crystallographic structure of the acetylcholinesterase with sequence from Electrophorus electricus was retrieved from the Protein Data Bank (PDB code: $1 \mathrm{C} 2 \mathrm{~B})^{[71]}$ as target protein. Missing atoms were reconstructed with SwissPDB Viewer 4.1.0. ${ }^{[72]}$ The docking experiments were carried out using the Lamarckian genetic algorithm implemented in the AutoDock 4.2 program. ${ }^{[73]} \mathrm{A}$ box encompassing both the CAS and the PAS site was defined for the exploration of possible binding modes. A volume for exploration was defined in the shape of a threedimensional cubic grid $\left(60 \times 74 \times 60 \AA^{3}\right)$ at a resolution of $0.3 \AA$ and centered on the gorge that enclosed the regions that are known to make up the inhibitors binding pockets and modes. Affinity grid files were generated using the auxiliary program AutoGrid. At each grid point, the receptor's atomic affinity potentials for carbon, oxygen, nitrogen, chloro and hydrogen atoms present in the ligand were precalculated for rapid intraand intermolecular energy evaluation of the docking solution. Different conformers of the ligands were docked by randomly changing the torsion angles and overall orientation of the molecule. The receptor residues Trp286, Tyr124, Tyr337, Tyr72, Asp74, Thr75, Trp86, and Tyr341 were selected to keep flexible during docking simulation with the AutoTors module. The program searched until a maximum of 100 conformations and the procedure was repeated 100 times (runs). After docking, the 100 solutions were clustered in groups with RMSD less than 1.5 $\AA$. The clusters were ranked by the lowest energy representative of each cluster. For all other parameters, the default values were used with AutoDock Tools. Due to the absence of X-ray structure of eqBuChE, a homology model was used to rationalize experimental data. To this end, the automated homology-modelling SWISS-MODEL program performed the modelling of the 3D structure. ${ }^{[72]}$ The three-dimensional structure of eqBuChE was created (UniProt Q9N1N9, modelled residue range: 32-562) based on the crystal structure of hBuChE (PDB: 2PM8). ${ }^{[7]}$ Docking calculations were performed following the same protocol described above for EeAChE. Additionally, we performed docking simulations with the crystallographic structure of the hBuCHE in complex with tacrine as protein target (PDB code: $4 \mathrm{BDS}){ }^{[46]}$ The results revealed that the tacrine moiety of the TFAH 10b occupies the same position that was observed in the original complex with tacrine (RMSD of 0.5 $\AA$ ). Moreover, the ligand binding pose is equivalent to that found for the docking study with the modeled 3D structure of eqBuChE. The same docking protocol was applied for the binding studies of TFAHs $10 \mathrm{e}$ and $10 \mathrm{~h}$ with the structure of human acetyl- (PDB code: $4 \mathrm{EY} 7)^{[45]}$ and butyrylcholinesterase (PDB code: 4BDS) ${ }^{[46]}$ as target proteins. Analogously, the docking experiments were carried out using the Lamarckian genetic algorithm implemented in the AutoDock 4.2 program. 
The docking method with the inclusion of seven structural water molecules was performed with the program Gold v.5.2 according to the method published by Darras et al. ${ }^{[49,75]}$ In preliminary docking runs the tacrine showed hydrogen bond interactions to the catalytic Ser203. Thus, a mild hydrogen bond constraint was placed on the hydroxyl oxygen to obtain an optimized binding pose. The top scored pose is shown in figure 5. Distances were measured between heavy atoms or between the heavy atom and the geometric centre of the His-ring in PyMOL. ${ }^{[50]}$

\section{Ex vivo Brain Penetration Study}

To test the brain permeability, the compound $10 \mathrm{a}$ was subjected to an ex vivo determination of its AChE inhibitory activity as previously described. ${ }^{[76,77]}$ Briefly, the compound was administered intraperitoneally (ip) to young adult Wistar rats (2 months of age) at either 10 or $50 \mu \mathrm{mol} . \mathrm{kg}^{-1}$. Experiments were performed in accordance with the Italian and European Community law for the use of experimental animals and were approved by a local bioethical committee. Animals were killed by decapitation at $2 \mathrm{~h}$ after injection, brain was immediately dissected and cortices from both hemispheres were collected. Tissues were homogenized in ice-cold $50 \mathrm{~mm}$ Tris- $\mathrm{HCl}$ buffer at $\mathrm{pH}=7.4$ and added with Triton $\mathrm{X}-100$ to a final $0.5 \%$ concentration (all chemicals were from Sigma-Aldrich). Homogenates were used to assay the AChE activity according to the standard colorimetric method ${ }^{[41]}$ and to measure the total protein content for normalization. ${ }^{[78]}$ AChE inhibition was not observed in the conditions used here.

In vitro Blood-Brain Barrier Permeation Assay (PAMPABBB). Prediction of the brain penetration was evaluated using a parallel artificial membrane permeation assay (PAMPA-BBB), in a similar manner as previously described. ${ }^{[62,16,63]}$ Pipetting was performed with a semi-automatic pipettor $\left(\mathrm{CyB}^{\circledR}\right.$-SELMA) and UV reading with a microplate spectrophotometer (Multiskan Spectrum, Thermo Electron Co.). Commercial drugs, phosphate buffered saline solution at $\mathrm{pH}=7.4$ (PBS), and dodecane were purchased from Sigma, Aldrich, Acros, and Fluka. Millex filter units (PVDF membrane, diameter $=25 \mathrm{~mm}$, pore size $=0.45 \mu \mathrm{m}$ ) were acquired from Millipore. The porcine brain lipid (PBL) was obtained from Avanti Polar Lipids. The donor microplate was a 96-well filter plate (PVDF membrane, pore size $0.45 \mu \mathrm{m}$ ) and the acceptor microplate was an indented 96-well plate, both from Millipore. The acceptor 96-well microplate was filled with $200 \mu \mathrm{L}$ of PBS:ethanol $(70: 30, \mathrm{v} / \mathrm{v})$ and the filter surface of the donor microplate was impregnated with $4 \mu \mathrm{L}$ of porcine brain lipid $(\mathrm{PBL})$ in dodecane $\left(20 \mathrm{mg} \cdot \mathrm{mL}^{-1}\right)$. Compounds were dissolved in PBS:ethanol $(70: 30, \mathrm{v} / \mathrm{v})$ at $100 \mu \mathrm{g} \cdot \mathrm{mL}^{-1}$, filtered through a Millex filter, and then added to the donor wells $(200 \mu \mathrm{L})$. The donor filter plate was carefully put on the acceptor plate to form a sandwich, which was left undisturbed for $120 \mathrm{~min}$ at $25^{\circ} \mathrm{C}$. After incubation, the donor plate is carefully removed and the concentration of compounds in the acceptor wells was determined by UV-Vis spectroscopy. Every sample is analyzed at five wavelengths, in four wells and at least in three independent runs, and the results are given as the mean \pm standard deviation. In each experiment, 11 quality control standards of known BBB permeability were included to validate the analysis set.

\section{ACKNOWLEDGMENTS}

The authors wish to thank the Regional Council of FrancheComté (France) for financial support and for awarding a Ph.D. grant to M. Benchekroun. We also thank Mrs. Marie-Jeanne Henriot from PHV Pharma for her technical support in HPLC measurements. Appreciation is expressed to Professor C. A. Sotriffer of Würzburg University for helpful discussions with $S$. Wehle. We gratefully acknowledge the German Academic National Foundation (Studienstiftung des deutschen Volkes) for awarding a Ph.D. scholarship to S. Wehle. M.I. RodríguezFranco acknowledges the financial support from the Spanish Ministry of Economy and Competitiveness (SAF2012-31035), CSIC (PIE-201280E074), and Fundación de Investigación Médica Mutua Madrileña Automovilística (AP103952012).

Keywords: Alzheimer's disease $\cdot$ antioxidants $\bullet$ cholinesterases inhibitors $\bullet$ multicomponent reactions $\bullet$ neuroprotection.

\section{GLOSSARY}

$\mathrm{AAPH}, \quad 2,2$ '-azobis(amidinopropane) dihydrochloride, $\mathrm{A} \beta, \quad \beta$ amyloid; ACh, acetylcholine; AChE, acetylcholinesterase; AChEls, acetylcholinesterase inhibitors; AD, Alzheimer's disease; ADMET, Absorption/Distribution/Metabolism/ Excretion/Toxicity; ATCh, acetylthiocholine iodide; BBB, bloodbrain barrier; BuChE, butyrylcholinesterase; BTCh, butyrylthiocholine iodide; CAS, catalytic anionic site; ChEs, cholinesterases; DMSO, dimethyl sulfoxide; DTNB, 5,5'dithiobis-2-nitrobenzoic acid; EDTA, 2,2',2",2'"-(Ethane-1,2diyldinitrilo)tetraacetic acid; EeAChE, Electricus Electrophorus acetylcholinesterase; eqBuChE, equine butyrylcholinesterase; EMEM, Eagle's minimum essential medium; FA, ferulic acid; FBS, fetal bovine serum; FDA, Food and Drug Administration; FL, fluorescein; hAChE, human recombinant acetylcholinesterase; hAChEls, human recombinant acetylcholinesterase inhibitors; hBuChE, human serum butyrylcholinesterase; hChEs, human cholinesterases; HepG2, human liver hepatocellular carcinoma cell line; HFIP, 1,1,1,3,3,3Hexafluoro-2-propanol; MeOH, methanol; MDTLs, multi-target directed ligands; 7-MEOTA, 9-amino7-methoxy-1,2,3,4tetrahydroacridine; MTT, 3-(4,5-dimethylthiazol-2-yl)-2,5diphenyl tetrazolium bromide; NFT, neurofibrillary tangles; O/R, oligomycin A/rotenone; ORAC-FL, oxygen radical absorbance capacity-fluorescein; PAMPA, parallel artificial membrane permeability assay); PAS, peripheral anionic site; PBL, porcine brain lipid; PC12, rat pheochromocytoma cell line; ROS, reactive oxygen species; $\mathrm{SH}-\mathrm{SY} 5 \mathrm{Y}$, human dopaminergic neuroblastoma cell line; TFAHs, tacrine-ferulic acid hybrids; ThT, thioflavin T, U4CR, Ugi four-component reaction. 
[1] P. Davies, A. J. Maloney, Lancet 1976, 2, 1403

[2] R. T. Bartus, R. L. 3rd Dean, B. Beer, A. S. Lippa, Science 1982, 217, 408-414.

[3] A. Cavalli, M. L. Bolognesi, A. Minarini, M. Rosini, V. Tumiatti, M. Recanatini, C. Melchiorre, J. Med. Chem. 2008, 51, 347-372.

[4] I. Tomassoli, L. Ismaili, M. Pudlo, C. de Los Ríos, E. Soriano, I. Colmena, L. Gandía, L. Rivas, A. Samadi, J. Marco-Contelles, et al., Eur. J. Med. Chem. 2011, 46, 1-10.

[5] A. Andreani, S. Burnelli, M. Granaiola, M. Guardigli, A. Leoni, A. Locatelli, R. Morigi, M. Rambaldi, M. Rizzoli, L. Varoli, et al., Eur. J. Med. Chem. 2008, 43, 657-661.

[6] D. Silva, M. Chioua, A. Samadi, P. Agostinho, P. Garção R. Lajarín-Cuesta, C. de los Ríos, I. Iriepa, I. Moraleda, L. Gonzalez-Lafuente, et al., ACS Chem. Neurosci. 2013, 4, 547-565.

[7] H. Soreq, S. Seidman, Nat. Rev. Neurosci. 2001, 2, 294302.

[8] M. Bartolini, C. Bertucci, V. Cavrini, V. Andrisano, Biochem. Pharmacol. 2003, 65, 407-416.

[9] A. Tasker, E. K. Perry, C. G. Ballard, Expert Rev. Neurother. 2005, 5, 101-106.

[10] Y. Furukawa-Hibi, T. Alkam, A. Nitta, A. Matsuyama, H. Mizoguchi, K. Suzuki, S. Moussaoui, Q.-S. Yu, N. H. Greig, T. Nagai, et al., Behav. Brain Res. 2011, 225, 222-229.

[11] L.-E. Cassagnes, V. Hervé, F. Nepveu, C. Hureau, P. Faller, F. Collin, Angew. Chem. Int. Ed. 2013, 52, 1111011113.

[12] Y. Christen, Am. J. Clin. Nutr. 2000, 71, 621S-629S.

[13] A. Contestabile, Behav. Brain Res. 2011, 221, 334-340.

[14] M. J. Knapp, D. S. Knopman, P. R. Solomon, W. W. Pendlebury, C. S. Davis, S. I. Gracon, JAMA 1994, 271, 985-991.

[15] P. B. Watkins, H. J. Zimmerman, M. J. Knapp, S. I. Gracon, K. W. Lewis, JAMA 1994, 271, 992-998.

[16] M. I. Fernández-Bachiller, C. Pérez, L. Monjas, J. Rademann, M. I. Rodríguez-Franco, J. Med. Chem. 2012, $55,1303-1317$.

[17] J. Patocka, D. Jun, K. Kuca, Curr. Drug Metab. 2008, 9, 332-335.

[18] J. Patocka, Sb. Ved. Prac. VLVDU Hradec Kralove 1986, 102, 123-140.

[19] J. L. Marx, Science 1987, 238, 1041-1042.

[20] D. J. Ames, P. S. Bhathal, B. M. Davies, J. R. Fraser, Lancet 1988, 1, 887

[21] A. Romero, R. Cacabelos, M. J. Oset-Gasque, A. Samadi, J. Marco-Contelles, Bioorg. Med. Chem. Lett. 2013, 23, 1916-1922.

[22] Y. Chen, J. Sun, L. Fang, M. Liu, S. Peng, H. Liao, J. Lehmann, Y. Zhang, J. Med. Chem. 2012, 55, 4309-4321.

[23] X. Chao, X. He, Y. Yang, X. Zhou, M. Jin, S. Liu, Z. Cheng, P. Liu, Y. Wang, J. Yu, et al., Bioorg. Med. Chem. Lett. 2012, 22, 6498-6502.

[24] L. Fang, B. Kraus, J. Lehmann, J. Heilmann, Y. Zhang, M. Decker, Bioorg. Med. Chem. Lett. 2008, 18, 2905-2909.

[25] R. Pi, X. Mao, X. Chao, Z. Cheng, M. Liu, X. Duan, M. Ye, X. Chen, Z. Mei, P. Liu, et al., PLoS ONE 2012, 7, e31921.

[26] J. E. Biggs-Houck, A. Younai, J. T. Shaw, Curr. Opin. Chem. Biol. 2010, 14, 371-382.

[27] A. Basiri, V. Murugaiyah, H. Osman, R. S. Kumar, Y. Kia K. B. Awang, M. A. Ali, Eur. J. Med. Chem. 2013, 67, 221229.

[28] O. Di Pietro, E. Viayna, E. Vicente-García, M. Bartolini, R. Ramón, J. Juárez-Jiménez, M. V. Clos, B. Pérez, V.
Andrisano, F. J. Luque, et al., Eur. J. Med. Chem. 2014, 73, 141-152.

[29] O. Di Pietro, F. J. Pérez-Areales, J. Juárez-Jiménez, A. Espargaró, M. V. Clos, B. Pérez, R. Lavilla, R. Sabaté, F. J. Luque, D. Muñoz-Torrero, Eur. J. Med. Chem. 2014, 84, 107-117.

[30] A. Dömling, W. Wang, K. Wang, Chem. Rev. 2012, 112, 3083-3135.

[31] T. J. Dickerson, A. E. Beuscher, C. J. Rogers, M. S. Hixon, N. Yamamoto, Y. Xu, A. J. Olson, K. D. Janda, Biochemistry 2005, 44, 14845-14853.

[32] N. C. Inestrosa, A. Alvarez, C. A. Pérez, R. D. Moreno, M. Vicente, C. Linker, O. I. Casanueva, C. Soto, J. Garrido, Neuron 1996, 16, 881-891.

[33] P. R. Carlier, E. S.-H. Chow, Y. Han, J. Liu, J. E. Yazal, Y.-P. Pang, J. Med. Chem. 1999, 42, 4225-4231.

[34] J. Bielavský, Collect. Czech. Chem. Commun. 1977, 42, 2802-2808.

[35] M. R. Del Giudice, A. Borioni, C. Mustazza, F. Gatta, A. Meneguz, M. T. Volpe, Il Farmaco 1996, 51, 693-698.

[36] K. Pérez-Labrada, I. Brouard, I. Méndez, D. G. Rivera, J. Org. Chem. 2012, 77, 4660-4670.

[37] M. Esquivias-Pérez, E. Maalej, A. Romero, F. Chabchoub, A. Samadi, J. Marco-Contelles, M. J. Oset-Gasque, Chem. Res. Toxicol. 2013, 26, 986-992.

[38] F. Denizot, R. Lang, J. Immunol. Methods 1986, 89, 271277.

[39] C. Shi, L. Zhao, B. Zhu, Q. Li, D. T. Yew, Z. Yao, J. Xu, Chem-Biol. Interact. 2009, 181, 115-123.

[40] G. C. González-Muñoz, M. P. Arce, B. López, C. Pérez, A Romero, L. del Barrio, M. D. Martín-de-Saavedra, J. Egea, R. León, M. Villarroya, et al., Eur. J. Med. Chem. 2011, 46, 2224-2235.

[41] G. L. Ellman, K. D. Courtney, V. Andres jr., R. M. Featherstone, Biochem. Pharmacol. 1961, 7, 88-95.

[42] B. Ou, M. Hampsch-Woodill, R. L. Prior, J. Agric. Food Chem. 2001, 49, 4619-4626.

[43] A. Dávalos, C. Gómez-Cordovés, B. Bartolomé, J. Agric. Food Chem. 2004, 52, 48-54.

[44] M. Bartolini, C. Bertucci, M. L. Bolognesi, A. Cavalli, C. Melchiorre, V. Andrisano, ChemBioChem 2007, 8, 21522161.

[45] J. Cheung, M. J. Rudolph, F. Burshteyn, M. S. Cassidy, E. N. Gary, J. Love, M. C. Franklin, J. J. Height, J. Med. Chem. 2012, 55, 10282-10286.

[46] F. Nachon, E. Carletti, C. Ronco, M. Trovaslet, Y. Nicolet, L. Jean, P.-Y. Renard, Biochem. J. 2013, 453, 393-399.

[47] J. Korabecny, K. Musilek, O. Holas, J. Binder, F. Zemek, J. Marek, M. Pohanka, V. Opletalova, V. Dohnal, K. Kuca, Bioorg. Med. Chem. Lett. 2010, 20, 6093-6095.

[48] I. Bolea, J. Juárez-Jiménez, C. de Los Ríos, M. Chioua, R Pouplana, F. J. Luque, M. Unzeta, J. Marco-Contelles, A. Samadi, J. Med. Chem. 2011, 54, 8251-8270.

[49] F. H. Darras, S. Wehle, G. Huang, C. A. Sotriffer, M. Decker, Bioorg. Med. Chem. 2014, 22, 4867-4881.

[50] The PyMOL Molecular Graphics System, Version 1.6.0.0, Schrödinger, LLC, New York, NY, 2013.

[51] ADMET Predictor, v.6.5 Simulations Plus, Inc. Lancaster, CA, 2013.

[52] ACD/Percepta 14.0.0, Advanced Chemistry Development Inc., Toronto, ON, Canada, 2013.

[53] Schrödinger Suite 2013-3: QuickProp, v.3.8, Schrödinger, LLC, New York, NY, 2013.

[54] I. Morigushi, S. Hirono, Q. Liu, I. Nakagome, Y. Matsushita, Chem. Pharm. Bull. 1992, 40, 127-130. 
[55] C. A. Lipinski, F. Lombardo, B. W. Dominy, P. J. Feeney, Adv. Drug Deliv. Rev. 2001, 46, 3-26.

[56] F. Atkinson, S. Cole, C. Green, H. van de Waterbeemd, Curr. Med. Chem. -Centr. Nerv. Syst. Agent 2002, 2, 229240.

[57] J. Kelder, P. D. Grootenhuis, D. M. Bayada, L. P. Delbressine, J. P. Ploemen, Pharm. Res. 1999, 16, 15141519.

[58] T. T. Wager, R. Y. Chandrasekaran, X. Hou, M. D. Troutman, P. R. Verhoest, A. Villalobos, Y. Will, ACS Chem. Neurosci. 2010, 1, 420-434.

[59] M. P. Gleeson, J. Med. Chem. 2008, 51, 817-834.

[60] P. A. Nielsen, O. Andersson, S. H. Hansen, K. B. Simonsen, G. Andersson, Drug Discov. Today 2011, 16, 472-475.

[61] L. Di, E. H. Kerns, K. Fan, O. J. McConnell, G. T. Carter, Eur. J. Med. Chem. 2003, 38, 223-232.

[62] M. I. Rodríguez-Franco, M. I. Fernández-Bachiller, C. Pérez, B. Hernández-Ledesma, B. Bartolomé, J. Med. Chem. 2006, 49, 459-462.

[63] B. López-Iglesias, C. Pérez, J. A. Morales-García, S. Alonso-Gil, A. Pérez-Castillo, A. Romero, M. G. López, M. Villarroya, S. Conde, M. I. Rodríguez-Franco, J. Med. Chem. 2014, 57, 3773-3785.

[64] T. Arendt, M. K. Brückner, M. Lange, V. Bigl, Neurochem. Int. 1992, 21, 381-396.

[65] S. Darvesh, D. A. Hopkins, C. Geula, Nat. Rev. Neurosci. 2003, 4, 131-138.

[66] N. H. Greig, T. Utsuki, D. K. Ingram, Y. Wang, G. Pepeu, C. Scali, Q.-S. Yu, J. Mamczarz, H. W. Holloway, T. Giordano, et al., Proc. Natl. Acad. Sci. U.S.A. 2005, 102, 17213-17218.

[67] R. B. Silverman, The Organic Chemistry of EnzymeCatalyzed Reactions, Academic Press, San Diego, 2000.

[68] H. Naiki, K. Higuchi, M. Hosokawa, T. Takeda, Anal. Biochem. 1989, 177, 244-249.

[69] H. 3rd LeVine, Protein Sci. 1993, 2, 404-410.

[70] A. J. S. Knox, M. J. Meegan, D. G. Lloyd, Curr. Top. Med. Chem. 2006, 6, 217-243.

[71] Y. Bourne, J. Grassi, P. E. Bougis, P. Marchot, J. Biol. Chem. 1999, 274, 30370-30376.

[72] SwissPdb Viewer 4.10, GlaxoSmithKline R\&D, Switzerland, 2012.

[73] G. M. Morris, R. Huey, W. Lindstrom, M. F. Sanner, R. K. Belew, D. S. Goodsell, A. J. Olson, J. Comput. Chem. 2009, 30, 2785-2791.

[74] M. N. Ngamelue, K. Homma, O. Lockridge, O. A. Asojo Acta Crystallogr. Sect. F Struct. Biol. Cryst. Commun. 2007, 63, 723-727.

[75] GOLDSUITE 5.2, CCDC Software, www.ccdc.cam.ac.uk, 2013.

[76] M. Rosini, E. Simoni, M. Bartolini, E. Soriano, J. Marco Contelles, V. Andrisano, B. Monti, M. Windisch, B. HutterPaier, D. W. McClymont, et al., ChemMedChem 2013, 8, 1276-1281.

[77] E. Nepovimova, E. Uliassi, J. Korabecny, L. E. PeñaAltamira, S. Samez, A. Pesaresi, G. E. Garcia, M. Bartolini, V. Andrisano, C. Bergamini, et al., J. Med. Chem. 2014, 57, 8576-8589.

[78] O. H. Lowry, N. J. Rosebrough, A. L. Farr, R. J. Randall, J. Biol. Chem. 1951, 193, 265-275. 


\title{
Entry for the Table of Contents
}

Layout 1:

\section{FULL PAPER}

\begin{abstract}
A multicomponent reaction for a multifactorial disease: New multipotent tacrine-ferulic acid hybrids (TFAHs) were synthesized by the Ugi four-component reaction and evaluated in vitro for the treatment of Alzheimer's disease. Among them, TFAH 10n was found to selectively inhibit the human butyrylcholinesterase. It also demonstrated good toxicity, neuroprotection, antioxydant and blood-brain barrier penetration profiles.
\end{abstract}

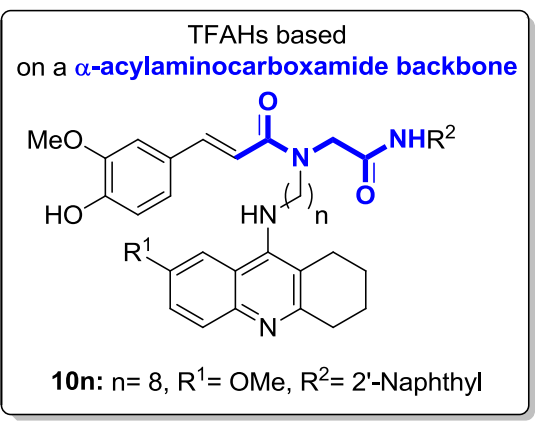

Mohamed Benchekroun, ${ }^{[a]}$ Manuela Bartolini, ${ }^{[b]}$ Javier Egea, ${ }^{[c]}$ Alejandro Romero, ${ }^{\left[{ }^{[d]}\right.}$ Elena Soriano, ${ }^{[e]}$ Marc Pudlo, ${ }^{[a]}$ Vincent Luzet, ${ }^{[a]}$ Vincenza Andrisano, ${ }^{[f]}$ María-Luisa Jimeno, ${ }^{[g]}$ Manuela G. López, ${ }^{[c]}$ Sarah Wehle, ${ }^{[h]}$ Tijani Gharbi, ${ }^{[a]}$ Bernard Refouvelet, ${ }^{[a]}$ Lucía de Andrés, ${ }^{[i]}$ Clara Herrera, ${ }^{[i]}$ Barbara Monti, ${ }^{[b]}$ Maria Laura Bolognesi, ${ }^{[b]}$ María Isabel RodríguezFranco, ${ }^{[i]}$ Michael Decker, ${ }^{[h]}$ José Marco-Contelles, ${ }^{*}\left[{ }^{2]}\right.$ and Lhassane Ismaili, ${ }^{*}[a]$

Novel Tacrine-Grafted Ugi Adducts as Multipotent Anti-Alzheimer Drugs: A Synthetic Renewal in Tacrine-Ferulic Acid Hybrids 